UC-25 Metals, Ceramics, and Materials (TID-4500, 21 st Ed.)

AEC Contract W-7405-eng-92

\title{
USE OF AGGLOMERATED UO2 IN PRESSURE-BONDED STAINLESS STEEL-CLAD FUEL RODS
}

\author{
by
}

Edwin S. Hodge

Stanley W. Porembka

Charles B. Boyer

Robert J. Diersing

July 23, 1963

BATTELLE MEMORIAL INSTITUTE 505 King Avenue Columbus 1, Ohio

This document is PUBLICLY RELEASABR $8 \mathrm{~cm}$ steale

Authorizing Official

Date: 


\section{DISCLAIMER}

This report was prepared as an account of work sponsored by an agency of the United States Government. Neither the United States Government nor any agency Thereof, nor any of their employees, makes any warranty, express or implied, or assumes any legal liability or responsibility for the accuracy, completeness, or usefulness of any information, apparatus, product, or process disclosed, or represents that its use would not infringe privately owned rights. Reference herein to any specific commercial product, process, or service by trade name, trademark, manufacturer, or otherwise does not necessarily constitute or imply its endorsement, recommendation, or favoring by the United States Government or any agency thereof. The views and opinions of authors expressed herein do not necessarily state or reflect those of the United States Government or any agency thereof. 


\section{DISCLAIMER}

Portions of this document may be illegible in electronic image products. Images are produced from the best available original document. 


\section{TABLE OF CONTENTS}

\section{Page}

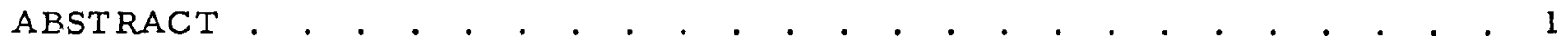

INTRODUCTION

PRESSURE-BONDED FUEL ASSEMBLIES . . . . . . . . . . . . . . . . . . $\quad$. 2

Oxide Consolidation and Loading of Fuel Rods. . . . . . . . . . . $\quad$. 2

Evaluation of Pressure-Bonded Fuel Rods . . . . . . . . . . . . 3

Metallographic Examination of Fuel Assemblies . . . . . . . . . . 3

EFFECTS OF PRESSURE-BONDING ON COLD-WORKED STAINLESS

STEEL CLADDING MATERIALS . . . . . . . . . . . . . . . . 10

Effect of Cold Working on the Grain Size of Pressure-Bonded Stainless

Steels . . . . . . . . . . . . . . . . . . . . . . . . 10

Effect of Prior Cold Work on the Mechanical Properties of Pressure-

Bonded Stainless Steels . . . . . . . . . . . . . . . . . . . 14

AGGLOMERATION STUDIES OF MICRONIZED URANIUM DIOXIDE . . . . . 20

Characterization of Micronized $\mathrm{UO}_{2}$.

Hydrostatic Agglomeration of Micronized Uranium Dioxide . . . . . . 22

Gas-Pressure Bonding of Agglomerated Micronized Uranium Dioxide . . . 22

Characterization of Pressure-Bonded Agglomerated Micronized

Uranium Dioxide . . . . . . . . . . . . . . . . . . . . 25

Discussion of Results of Agglomeration Study . . . . . . . . . . . $\quad$. 27

CONCLUSIONS . . . . . . . . . . . . . . . . . . . . . . . . . . .

REFERENCES . . . . . . . . . . . . . . . . . . . . . . . . . 28 


\section{USE OF AGGLOMERATED UO 2 IN PRESSURE-BONDED STAINLESS STEEL-CLAD FUEL RODS}

Edwin S. Hodge, Stanley W. Porembka, Charles B. Boyer, and Robert J. Diersing

In a continuation of the Hanford-Battelle cooperative program reported in BMI-1637, the combined use of the vibrational compaction and gas-pressure-. bonding processes for fabricating $\mathrm{UO}_{2}$ fuel elements was studied. Particular emphasis was placed on the use of agglomerated Micronized $\mathrm{UO}_{2}$ to overcome nonuniformities in the vibrationally compacted pressure-bonded fuels. Inconel $X$-clad fuel rods were gas-pressure bonded at $2100 \mathrm{~F}$ for 3 hr at 10,000 psi to evaluate the use of Micronized $\mathrm{UO}_{2}$ agglomerated by cold high-energy-rate forming methods. Fuel densities from 88 to 93 per cent of theoretical were attained. A limited parallel study was also conducted to evaluate hydrostatic pressing as a method of agglomerating Micronized $U_{2} O_{2}$. Tap density increased from 20 to 25 per cent for the as-received Micronized oxide to 41 per cent for the hydrostatically agglomerated plus 200-mesh powder. Studies of the effects of prior cold work and gas-pressure bonding on the mechanical and physical properties of Types $304 \mathrm{~L}$ and 347 stainless were conducted. Prior cold work in the range of 35 to 50 per cent gave a pressure-bonded structure having a fine grain size.

\section{INTRODUCTION}

A recent cooperative program between Battelle and the General Electric Hanford Laboratories was initiated to study the combined use of vibrational compaction and gaspressure-bonding processes as a possible low-cost method for fabricating uranium dioxide fuel elements. Earlier work at Hanford demonstrated that high unbonded $\mathrm{UO}_{2}$ densities are possible by vibrational compaction of special particle-size formulations. (1) Similarly, Battelle studies conducted under the USAEC Fuel-Cycle Development Program showed that simultaneous high densification of $\mathrm{UO}_{2}$ and cladding with stainless steel could be achieved by gas-pressure bonding. $(2,3)$ It appeared that the combined use of the two processes would be particularly attractive since it would permit elimination of the inherently expensive cold-pressing and sintering operations used in the conventional fabrication of $\mathrm{UO}_{2}$ fuel rods.

Initial efforts in this cooperative program involved a study of process and material variables with respect to the appearance and uniformity of the final fuel rods. (4) The variables included particle-size formulations, Micronized $\mathrm{UO}_{2}$ additions, cladding material, and cladding thickness and the use of intermediate swaging. As a result of this work it was found that $\mathrm{UO}_{2}$ mixtures containing 30 to $40 \mathrm{w} / 0$ Micronized $\mathrm{UO}_{2}$ with a maximum coarse particle size of 20 mesh were required to produce high-density fuel rods by the combined process. Related studies concerning the effects of pressure bonding on the properties of stainless steel cladding indicated the desirability of Type 347 stainless steel for such processing.

*References at end. 
The research efforts discussed in the present report represent a continuation of these investigations with particular emphasis on the use of agglomerated Micronized UO; to overcome nonuniformities in the vibrational compacted pressure-bonded fuels. Both the hydrostatic and cold high-energy-rate forming methods were evaluated in this regard. Predensification processing involved both vibrational compaction and cold swaging with the latter process applied to mixtures with high contents of nonagglomerated Micronized $\mathrm{UO}_{2}$. In addition, studies initiated earlier of the effects of prior cold work and pressure bonding on the properties of stainless steel were continued.

\section{PRESSURE-BONDED FUEL ASSEMBLIES}

\section{Oxide Consolidation and Loading of Fuel Rods}

Initially, fuel-rod samples for this study were to be clad with Type 347 stainless steel. This cladding material was selected because of those alloys suited to this application it provided the smallest grain size in the cladding structure after pressure bonding. However, delivery of the Type 347 stainless steel tubing required for this study could not be obtained in a reasonable length of time, and Inconel $\mathrm{X}$ tubing available at Hanford was selected as an alternative.

Thirty-one rods, which represented the seventh series supplied by Hanford in the cooperative program, were used in this study. Seven types of $\mathrm{UO}_{2}$ cores differing in oxide composition and predensification method were used. The predensification riethods applied to these rods consisted of either cold swaging or vibrational compaction. Both techniques were of interest in this investigation since previous work with the oxide formulations used showed that vibrational compaction yielded marginal starting densities and indicated the potential of cold swaging. (4) Micronized, fused, and electrodeposited $\mathrm{UO}_{2}$ powders were used in preparation of the fuel-rod cores. The Micronized oxide was employed both as prepared and as an agglomerated powder produced by high-energy forming and subsequent granulation. This material was used alone and in combination with the fused and electrodeposited oxides in mixtures having various size fractions.

On the cold-swaged rods, the initial cladding was $0.750-$ in. - OD Inconel $X$ tubing with a 0.015 -in. -thick wall. Swaging at Hanford reduced the diameter of these rods to between 0.540 and $0.575 \mathrm{in.}$ Inconel $X$ tubing, 0.563 in. in $O D$ with a 0.010 -in. -thick wall was used as the cladding on the vibrationally compacted rods, all of which were also given a subsequent light swaging pass to improve the packing density. This swaging operation reduced the diameter of the cladding to an average of 0.505 in.

When the rods were received from Hanford, they were radiographed to determine fuel uniformity. The radiographs indicated that the tapered end plugs used in these as semblies could cause possible difficulties with cladding deformation at the end plugfuel interfaces.

Prior to pressure bonding, the rods were checked for gas leaks in a gastight chamber under 300 psi of helium. Of the 31 rods received from Hanford, 11 rods leaked 
under pressure in the end-cap weld areas. This behavior confirmed the indications found by radiography that welding of the end plugs and deformation of the cladding near the tapered end plugs could be a cause of leaks in this area of the fuel element. Attempts to repair the welds in the end cap areas by electron-beam welding were not successful. Gas release occurred during the electron-beam welding.

\section{Evaluation of Pressure-Bonded Fuel Rods}

The 20 fuel rods which did not leak upon pressure checking were gas-pressure bonded at $2100 \mathrm{~F}$ for $3 \mathrm{hr}$ at $10,000 \mathrm{psi}$. The bonding conditions were selected according to past experience with the cladding materials and fuel-element geometries. Of the 20 rods that were pressure bonded, 12 leaked during pressure checking after bonding, either due to collapse of the cladding near the end caps or to cracking at pleats in the cladding along the length of the fuel element. In this respect, the Inconel $X$ cladding appeared to behave in a more brittle manner than the Type 304L stainless steel cladding used in previous studies.

Four fuel rods were sectioned at Battelle and evaluated on the basis of fuel density, dimensional uniformity, microstructure, and oxygen-to-uranium fuel ratios at three points along their length. Four rods were given a similar examination at HAPO. The data and results obtained for these fuel rods are summarized in Table 1. The results indicated that the cold $\mathrm{HEF} \mathrm{UO}_{2}$ retained excess oxygen during the pressure bonding run. This finding was in contrast to previous experience with similar oxide formulations employing as-received Micronized oxide. Also, it was evident that the final densities were lower than those obtained in previous work. Reduction of the diameter by approximately 5 per cent occurred on those rods which did not leak during pressure bonding. Dimensional changes were taken with a micrometer at three selected places along the length of the rod and recorded. In general, the rods had slightly wrinkled cladding surfaces but remained straight. In some rods, deformation of the cladding occurred adjacent to the end plugs.

\section{Metallographic Examination of Fuel Assemblies}

Metallographic examination at Battelle of the four rods selected for sampling demonstrated varying effects. A structure of the cold-swaged and pressure-bonded rod containing cold high-energy-formed Micronized $\mathrm{UO}_{2}$ is shown in Figure 1. A highdensity structure is apparent, and the inclusion of a minor amount of small fused particles is evident. It is interesting to note, however, that the structure does not correspond with the measured density of 88.7 per cent of theoretical, but has an appearance characteristic of a high-density structure, indicating that considerable ceramic activity has been retained in the HEF material. Structures of oxide mixtures which were initially vibrationally compacted are shown in Figures 2 and 3, representing a rod exhibiting a leak after bonding and a rod with a sound cladding, respectively. From this comparison it is evident that the cladding leak in the former case occurred during the bonding operation. Little difference can be noted in samples employing fused or electrodeposited coarse oxides, as shown in Figures 3 and 4 . In these structures the cold HEF material has densified uniformly, and porosity is apparent in both types of coarse particles. 
TABLE 1. EFFECTS OF GAS-PRESSURE BONDING ON INCONEL $X-C L A D$ UO ${ }_{2}$ FUEL RODS

\begin{tabular}{|c|c|c|c|c|c|c|c|c|c|c|}
\hline \multirow{2}{*}{\multicolumn{3}{|c|}{ Uranium Oxide Composition }} & \multirow[b]{3}{*}{ Predensification } & \multirow{3}{*}{$\begin{array}{l}\text { Cladding } \\
\text { Thickness, } \\
\text { in. }\end{array}$} & \multirow[b]{3}{*}{ Rod } & \multirow{3}{*}{$\begin{array}{l}\text { Outside Diameter } \\
\text { Cladding Prior to } \\
\text { Pressure Bonding(a), } \\
\text { in. }\end{array}$} & \multicolumn{3}{|c|}{$\begin{array}{c}\text { Specimen Characterization(a) } \\
\text { After Gas-Pressure Bonding } 3 \mathrm{Hr} \\
\text { at } 2100 \mathrm{~F} \text { and } 10,000 \text { PSI }\end{array}$} & \multirow[b]{3}{*}{ Comments } \\
\hline & & & & & & & \multirow{2}{*}{$\begin{array}{l}\text { Outside } \\
\text { Diameter, } \\
\text { in. }\end{array}$} & \multirow{2}{*}{$\begin{array}{l}\text { Oxygen/ } \\
\text { Uranium } \\
\text { Ratio }\end{array}$} & \multirow{2}{*}{$\begin{array}{l}\text { Average } \\
\text { Density, } \\
\text { per cent of } \\
\text { theoretical }\end{array}$} & \\
\hline $\begin{array}{c}\text { Amount, } \\
\mathrm{w} / \mathrm{o}\end{array}$ & Type Powder & $\begin{array}{l}\text { Mesh } \\
\text { Size }\end{array}$ & & & & & & & & \\
\hline \multirow[t]{4}{*}{100} & \multirow[t]{4}{*}{ Cold HEF } & \multirow[t]{4}{*}{-35} & \multirow[t]{4}{*}{ Cold swaging } & \multirow[t]{4}{*}{0.015} & $74-1$ & 0.542 & 0.490 & $2.068^{(b)}$ & $87.5^{(b)}$ & Postbonding pressure checked $\mathrm{O} . \mathrm{K}$. \\
\hline & & & & & $74-2$ & 0.542 & -- & -- & -- & Prebonding pressure check showed leak \\
\hline & & & & & $74-3$ & 0.543 & 0.513 & $2.059^{(b)}$ & $88.0^{(b)}$ & Postbonding pressure checked $\mathrm{O} . \mathrm{K}$. \\
\hline & & & & & $74-4$ & 0.540 & 0.479 & 2.064 & 88.7 & Postbonding pressure checked $\mathrm{O} . \mathrm{K}$. \\
\hline \multirow[t]{5}{*}{$\begin{array}{l}70 \\
30\end{array}$} & \multirow[t]{5}{*}{$\begin{array}{l}\text { HEF } \\
\text { Cold HEF }\end{array}$} & \multirow[t]{5}{*}{$\begin{array}{l}-35+65 \\
-200\end{array}$} & \multirow[t]{5}{*}{$\begin{array}{l}\text { Vibrational } \\
\text { compaction }(c)\end{array}$} & \multirow[t]{5}{*}{0.010} & $75-1$ & 0.508 & -- & -- & -- & $\begin{array}{l}\text { Postbonding pressure check showed leak; } \\
\text { no deformation }\end{array}$ \\
\hline & & & & & $75-2$ & 0.505 & -- & - & - & Prebonding pressure check showed leak \\
\hline & & & & & $75-3$ & 0.506 & -- & $\rightarrow$ & -- & Prebonding pressure check showed leak \\
\hline & & & & & $75-4$ & 0.508 & 0.530 & -- & $\cdots$ & $\begin{array}{l}\text { Postbonding pressure check showed leak; } \\
\text { no deformation }\end{array}$ \\
\hline & & & & & $75-5$ & 0.505 & $\cdots$ & $=-$ & -- & $\begin{array}{l}\text { Postbonding pressure check showed leak; } \\
\text { no deformation }\end{array}$ \\
\hline \multirow[t]{4}{*}{$\begin{array}{l}70 \\
30\end{array}$} & \multirow[t]{4}{*}{$\begin{array}{l}\text { Fused } \\
\text { Cold HEF }\end{array}$} & \multirow[t]{4}{*}{$\begin{array}{l}-35+65 \\
-200\end{array}$} & \multirow[t]{4}{*}{$\begin{array}{l}\text { Vibrational } \\
\text { compaction }(\mathrm{c})\end{array}$} & \multirow[t]{4}{*}{0.010} & $76-1$ & 0.504 & -- & - & -- & Prebonding pressure check showed leak \\
\hline & & & & & $76-2$ & 0.505 & 0.530 & -- & -- & $\begin{array}{l}\text { Postbonding pressure checked } \mathrm{O} . \mathrm{K} \text {. } \\
\text { bloated, no deformation }\end{array}$ \\
\hline & & & & & $76-3$ & 0.503 & 0.508 & -- & -- & $\begin{array}{l}\text { Postbonding pressure check showed leak } \\
\text { at pleat }\end{array}$ \\
\hline & & & & & $76-4$ & 0.503 & 0.505 & 2.015 & 86.0 & $\begin{array}{l}\text { Postbonding pressure check showed leak; } \\
\text { no deformation }\end{array}$ \\
\hline $\begin{array}{l}70 \\
30\end{array}$ & $\begin{array}{c}\text { Fused } \\
\text { Micronized }\end{array}$ & \multirow[t]{2}{*}{$-35+65$} & $\begin{array}{l}\text { Vibrational } \\
\text { compaction(c) }\end{array}$ & 0.010 & $77-1$ & 0.501 & -- & -- & - & Prebonding pressure check showed leak \\
\hline $\begin{array}{l}70 \\
30\end{array}$ & $\begin{array}{l}\text { Fused } \\
\text { Micronized }\end{array}$ & & $\begin{array}{l}\text { Vibrational } \\
\text { compaction }(c)\end{array}$ & 0.010 & $77-2$ & 0.503 & -- & -- & -- & Prebonding pressure check showed leak \\
\hline & & & & & $77-3$ & 0.502 & 0.515 & $\cdots$ & -- & $\begin{array}{l}\text { Postbonding pressure check showed leak; } \\
\text { kinking at end }\end{array}$ \\
\hline & & & & & $77-4$ & 0.504 & 0.517 & - & -- & $\begin{array}{l}\text { Postbonding pressure check showed leak; } \\
\text { no deformation, loose core }\end{array}$ \\
\hline $\begin{array}{l}70 \\
30\end{array}$ & $\begin{array}{l}\text { Electrodeposited } \\
\text { Cold HEF }\end{array}$ & $\begin{array}{l}-35+65 \\
-200\end{array}$ & $\begin{array}{l}\text { Vibrational } \\
\text { compaction } \\
(c)\end{array}$ & 0.010 & $78-1$ & 0.505 & 0.481 & 2.024 & 93.6 & $\begin{array}{l}\text { Postbonding pressure check showed no } \\
\text { leaks }\end{array}$ \\
\hline & & & & & $78-2$ & 0.505 & - & - & -- & Prebonding pressure check showed leak \\
\hline & & & & & $78-3$ & 0.506 & -- & -- & -- & Prebonding pressure check showed leak \\
\hline & & & & & $78-4$ & 0.506 & 0.505 & - & - & $\begin{array}{l}\text { Postbonding pressure check showed leak; } \\
\text { pleated effect }\end{array}$ \\
\hline & & & & & $78-5$ & 0.505 & 0.505 & - & - & $\begin{array}{l}\text { Postbonding pressure check showed leak; } \\
\text { kinked, leak at kink }\end{array}$ \\
\hline
\end{tabular}


TABLE 1. (Continued)

\begin{tabular}{|c|c|c|c|c|c|c|c|c|c|c|}
\hline \multirow{2}{*}{\multicolumn{3}{|c|}{ Uranium Oxide Composition }} & \multirow[b]{3}{*}{ Predensification } & \multirow{3}{*}{$\begin{array}{l}\text { Cladding } \\
\text { Thickness, } \\
\text { in. }\end{array}$} & \multirow[b]{3}{*}{ Rod } & \multirow{3}{*}{$\begin{array}{l}\text { Outside Diameter } \\
\text { Cladding Prior to } \\
\text { Pressure Bonding }{ }^{(a)} \text {. } \\
\text { in. }\end{array}$} & \multicolumn{3}{|c|}{$\begin{array}{c}\text { Specimen Characterization (a) } \\
\text { After Gas-Pressure Bonding } 3 \mathrm{Hr} \\
\text { at } 2100 \mathrm{~F} \text { and } 10,000 \mathrm{PSI} \\
\end{array}$} & \multirow[b]{3}{*}{ Comments } \\
\hline & & & & & & & \multirow{2}{*}{$\begin{array}{l}\text { Outside } \\
\text { Diameter, } \\
\text { in. }\end{array}$} & \multirow{2}{*}{$\begin{array}{l}\text { Oxygen/ } \\
\text { Uranium } \\
\text { Ratio }\end{array}$} & \multirow{2}{*}{$\begin{array}{l}\text { Average } \\
\text { Density, } \\
\text { per cent of } \\
\text { theoretical }\end{array}$} & \\
\hline $\begin{array}{l}\text { Amount, } \\
\text { w/o }\end{array}$ & Type Powder & $\begin{array}{l}\text { Mesh } \\
\text { Size }\end{array}$ & & & & & & & & \\
\hline 70 & HEF & $-35+65$ & Cold swaged & 0.015 & $79-1$ & 0.574 & - & $\cdots$ & -- & Prebonding check showed leak \\
\hline \multirow[t]{4}{*}{30} & Cold HEF & -200 & & & & & & & & \\
\hline & & & & & $79-2$ & 0.571 & 0.595 & $2.018^{(b)}$ & $93.7^{(b)}$ & $\begin{array}{l}\text { Postbonding pressure check showed no } \\
\text { leaks }\end{array}$ \\
\hline & & & & & $79-3$ & 0.575 & 0.596 & -- & -- & $\begin{array}{l}\text { Postbonding pressure check showed no } \\
\text { leaks; core loose }\end{array}$ \\
\hline & & & & & $79-4$ & 0.573 & -. & -- & - & Prebonding pressure check showed leak \\
\hline 70 & Electrodeposited & $-35+65$ & Cold swaged & 0.015 & $80-1$ & 0.575 & 0.594 & -- & - & Postbonding pressure check showed leak \\
\hline \multirow[t]{5}{*}{30} & Cold HEF & -200 & & & & & & & & at the end cap \\
\hline & & & & & $80-2$ & 0.574 & -. & 2.023 & 92.0 & Postbonding pressure check showed leak \\
\hline & & & & & $80-3$ & 0.575 & $\begin{array}{l}0.584 \text { to } \\
0.621\end{array}$ & -- & $\cdots$ & $\begin{array}{l}\text { Postbonding pressure check showed leak; } \\
\text { bubbled and bloated }\end{array}$ \\
\hline & & & & & $80-4$ & 0.574 & - & -- & -- & Prebonding pressure check showed leak \\
\hline & & & & & $80-5$ & 0.575 & $\begin{array}{l}0.566 \text { to } \\
0.613\end{array}$ & $2.021^{(b)}$ & $90.2^{(\mathrm{b})}$ & $\begin{array}{l}\text { Postbonding pressure check showed no } \\
\text { leaks; bloated, no deformation }\end{array}$ \\
\hline
\end{tabular}

(a) Data obtained at three locations along the length of the rod.

(b) Hanford values; each density value is an average of two determinations.

(c) Vibrationally compacted rods were also given a light swaging to improve packing density. 


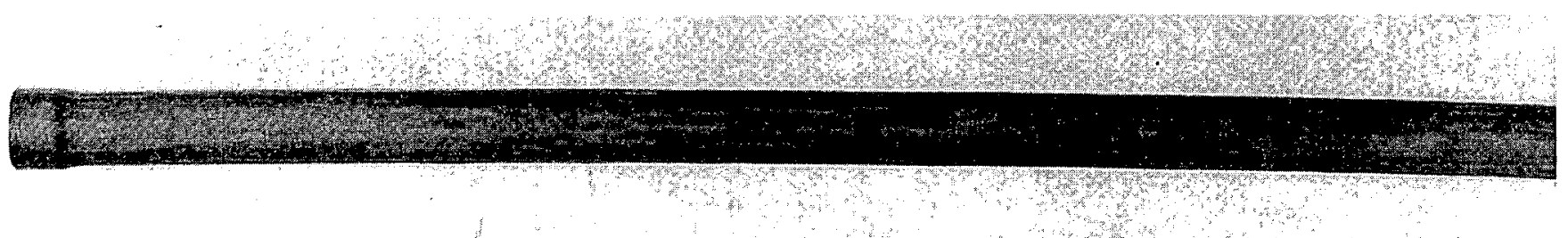

$1 / 2 \mathrm{X}$

N98415

a. Over-All View

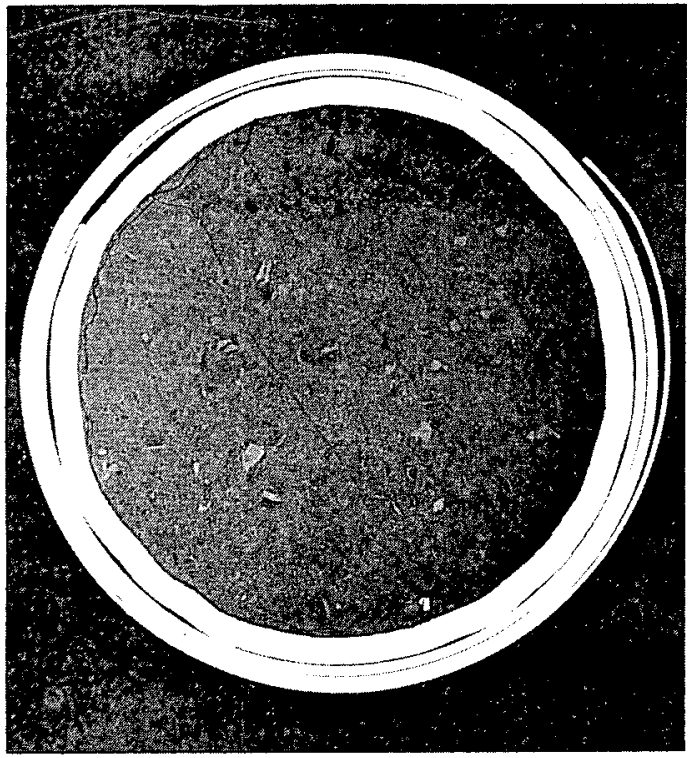

$4 X$
RM24413

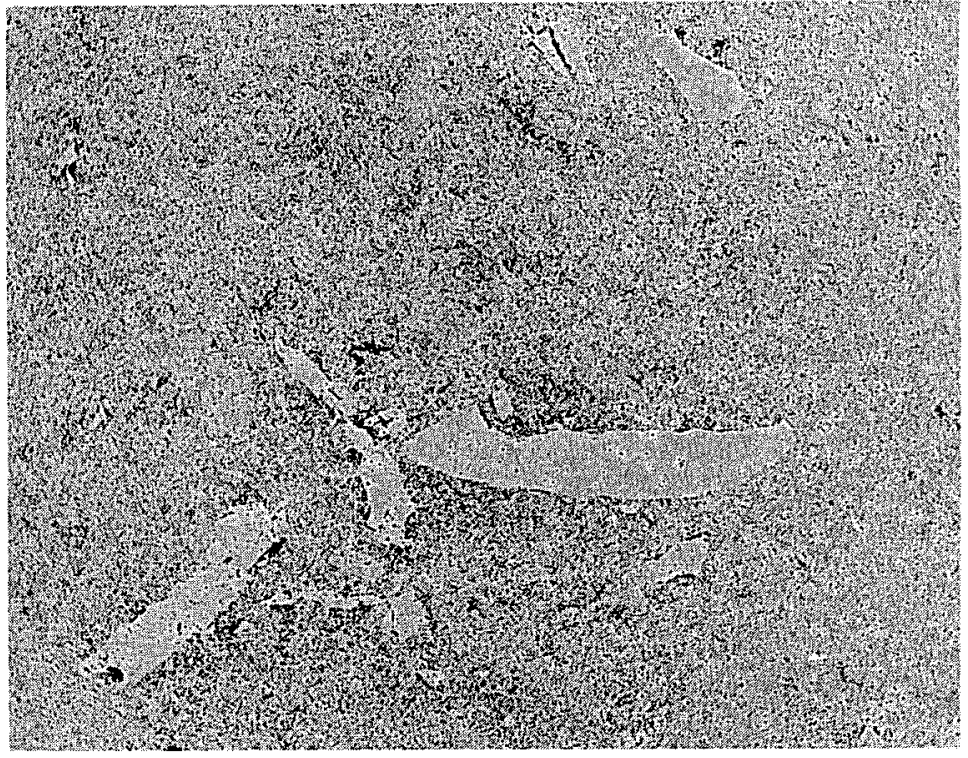

$250 X$

RM24412

b. Cross Section

c. Core Microstructure

FIGURE 1. INCONEL $X$-CLAD UO 2 COLD SW AGED AND PRESSURE BONDED AT $2100 \mathrm{~F}$ FOR 3 HR AT 10,000 PSI TO A FINAL DENSITY OF 88.7 PER CENT OF THEORETICAL (ROD 74-4)

The core material is 100 per cent cold HEF minus 35-mesh $\mathrm{UO}_{2}$. A highdensity structure containing a minor amount of small fused particles is evident. 


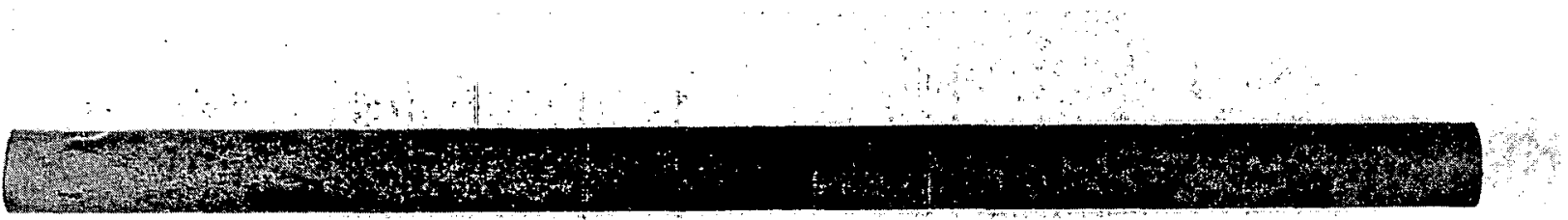

$1 / 2 \mathrm{X}$

N98412

a. Over-All View

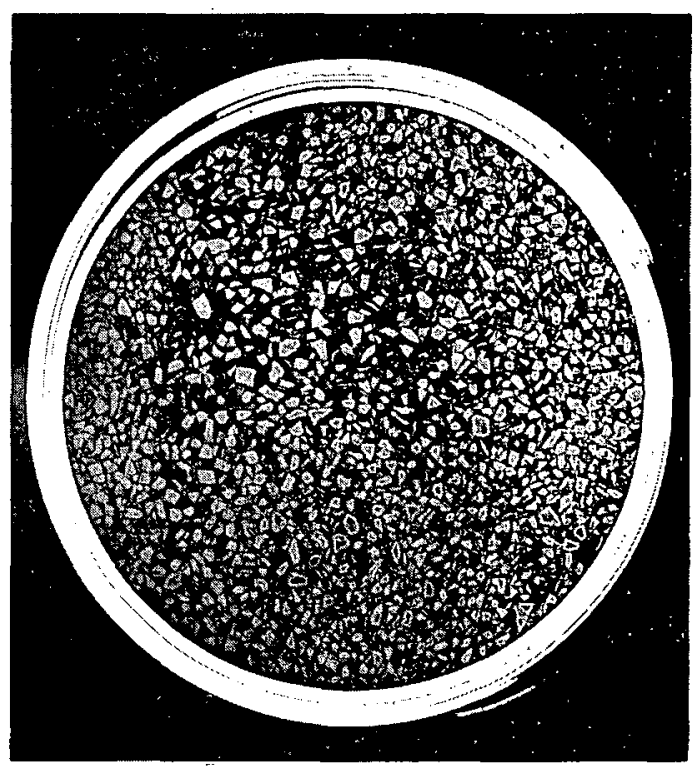

$4 \mathrm{X}$

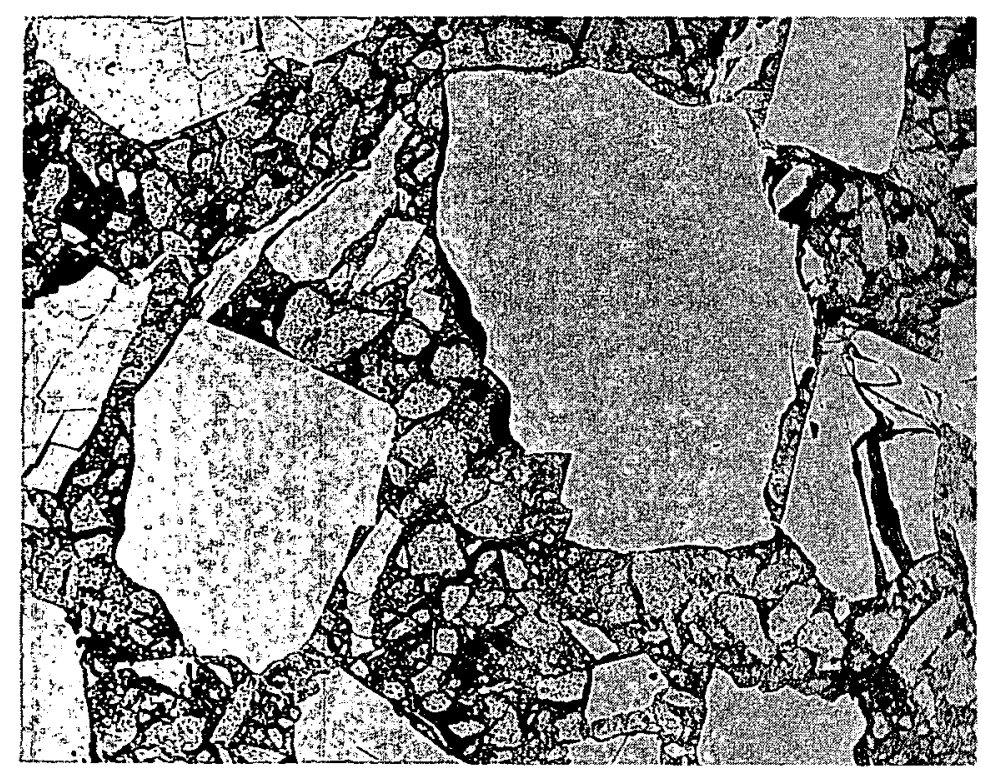

RM24411

b. Cross Section

c. Core Microstructure

FIGURE 2. INCONEL $X$-CLAD UO 2 ROD VIBRATIONALLY COMPACTED AND COLD SWAGED LIGHTLY THEN PRESSURE BONDED AT 2100 F FOR 3 HR AT 10,000 PSI TO A FINAL DENSITY OF 86. 0 PER CENT OF THEORETICAL (ROD 76-4)

The core material is a mixture of $30 \mathrm{w} / \mathrm{o}$ minus $200-$ mesh HEF and $70 \mathrm{w} / 0$ minus 35 plus 65-mesh fused $\mathrm{UO}_{2}$. The cladding leaked during gas-pressure bonding. 

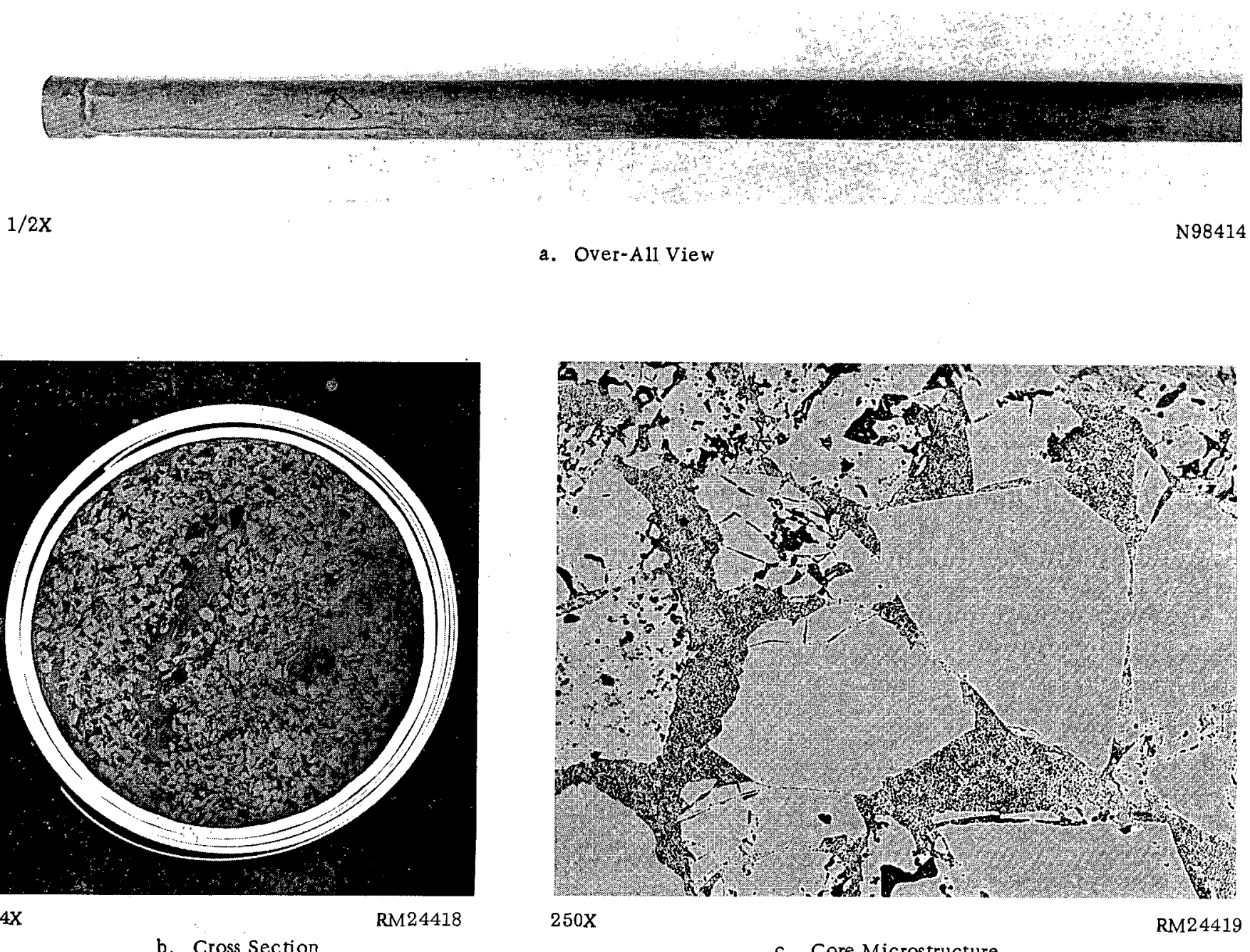

b. Cross Section
RM24418

$4 \mathrm{X}$

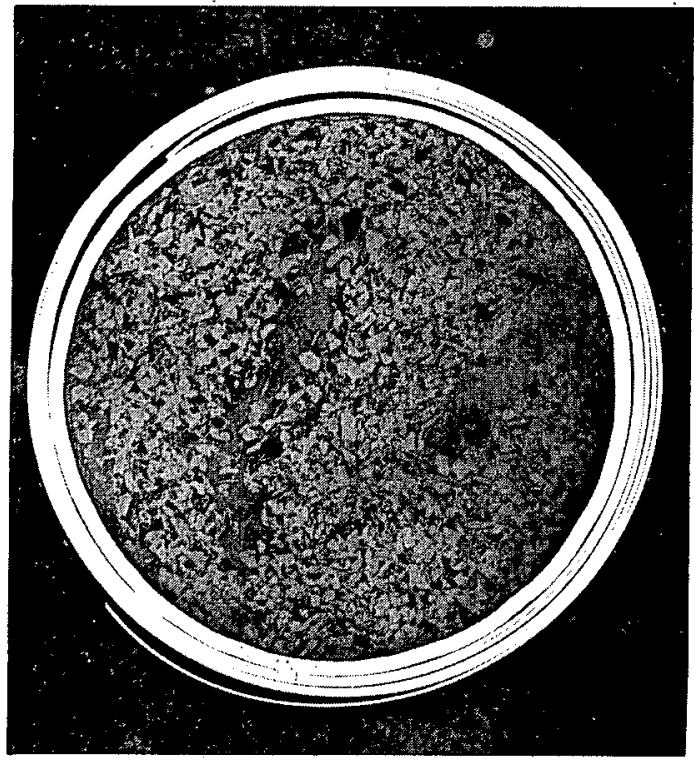

c. Gore Microstructure

FIGURE 3. INCONEL X-CLAD UO 2 ROD VIBRATIONALLY COMPACTED AND COLD SWAGED LIGHTLY THEN PRESSURE BONDED AT 2100 F FOR 3 HR AT 10,000 PSI TO A FINAL DENSITY OF 93.6 PER CENT OF THEORETICAL (ROD 78-1)

The core is a mixture of $30 \mathrm{w} / 0$ minus $200-$ mesh HEF and $70 \mathrm{w} / 0$ minus 35 plus 65-mesh electrodeposited $\mathrm{UO}_{2}$. 


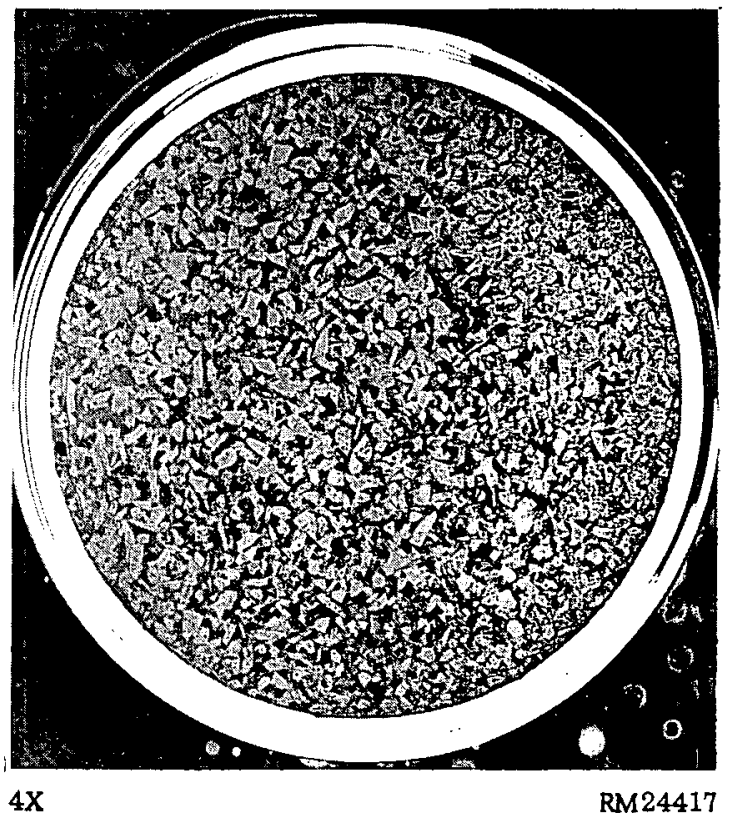

b. Cross Section

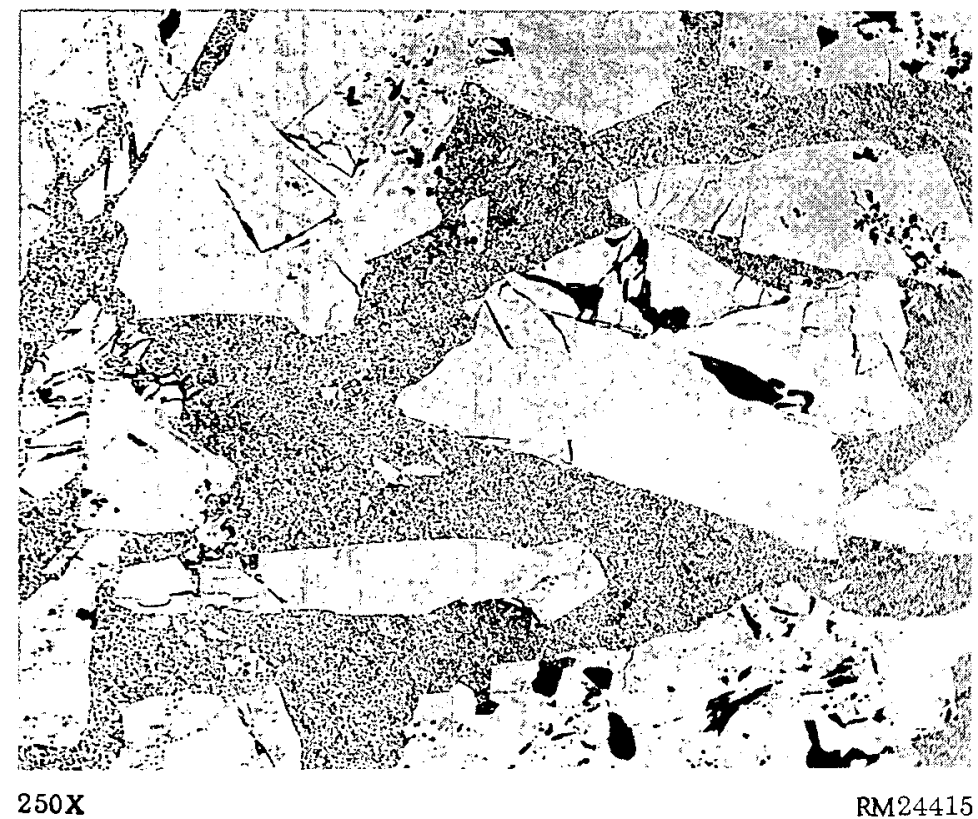

c. Core Microstructure

FIGURE 4. INCONEL X-CLAD UO ${ }_{2}$ COLD SWAGED AND PRESSURE BONDED AT $2100 \mathrm{~F}$ FOR 3 HR AT 10,000 PSI TO A FINAL DENSITY OF 92.0 PER CENT OF THEORETICAL (ROD 80-2)

The core is a mixture of $30 \mathrm{w} / \mathrm{o}$ minus 200 -mesh HEF and $70 \mathrm{w} / \mathrm{o}$ minus 35 plus 65-mesh electrodeposited $\mathrm{UO}_{2}$ 
The $\mathrm{UO}_{2}$ core-Inconel $\mathrm{X}$ interfaces observed in the four rods examined at Battelle are shown in Figure 5. There was a light-colored, thin, continuous phase approximately 20 to $30 \mu$ thick separating the $\mathrm{UO}_{2}$ and Inconel $\mathrm{X}$. Electron-probe microanalysis and metallurgical examination in polarized light, suggested that this phase was probably $\mathrm{Cr}_{2} \mathrm{O}_{3}$, chromic oxide. However, positive identification of this phase in the Inconel X$\mathrm{UO}_{2}$ interface was not established.

\section{EFFECTS OF PRESSURE-BONDING ON COLD-WORKED STAINLESS STEEL CLADDING MATERIALS}

During past gas-pressure-bonding studies of stainless steel-clad fuel elements, it was noticed that the bonding cycle affected the microstructure of the stainless steel. $(5,3)$ Subjecting Types 304 and $304 \mathrm{~L}$ stainless steels to extended bonding times of up to $4 \mathrm{hr}$ at temperatures in the range of 1900 to $2100 \mathrm{~F}$ caused excessive grain growth in the cladding. The slow cooling that normally occurs during the pressure bonding cycle caused carbide precipitation to occur in those types of stainless steels which were not stabilized or were not of a low-carbon variety. The corrosion resistance and mechanical properties would be expected to be affected deleteriously by the precipitated grain-boundary carbides in such stainless steels. In the present program a study of this behavior was initiated to obtain a more complete understanding of the effects of the pressure-bonding cycle on the mechanical and metallurgical properties of stainless steel cladding materials. Of particular interest to this study was the large grain size observed in Type $304 \mathrm{~L}$ stainless steel in past pressure-bonding studies. Also, a prior study had demonstrated that Type 347 exhibited a much finer grain size after a similar bonding treatment. (6) On the basis of these observations, these two types of stainless steels were selected as the materials for this study.

This study concentrated on reducing the grain size by cold working the stainless prior to pressure bonding. To determine the amount of cold work which will yield the smallest grain size after pressure bonding, specimens were cold rolled 5 to 60 per cent in intervals of 5 per cent. Similarly, Type 347 stainless steel was cold worked in the same manner from 5 to 35 per cent to compare grain-size effects with those in the Type $304 \mathrm{~L}$ alloy. In this manner, a minimum recrystallized grain size was found for each material. The gas-pressure-bonding cycle concerned was $2100 \mathrm{~F}$ at $3 \mathrm{hr}$ and $10,000 \mathrm{psi}$, which represented the bonding temperature known to yield high-strength solid-phase bonds of stainless steels.

Types $304 \mathrm{~L}$ and 347 stainless steel stock 100 mils thick was obtained in the asannealed condition. Typical as-received microstructures are shown in Figure 6.

Effect of Cold Working on the Grain Size of Pressure-Bonded Stainless Steels

Since the primary interest of this study was to determine the smallest recrystallized grain size possible after pressure bonding, a metallographic examination for grain size comparison was made. The ASTM grain size was rated at $100 \mathrm{X}$ with a Bausch \& Lomb micrometer eyepiece on a Research Metallograph. Tables 2 and 3 summarize the results of the grain-size determination on Types $304 \mathrm{~L}$ and 347 stainless steels. 


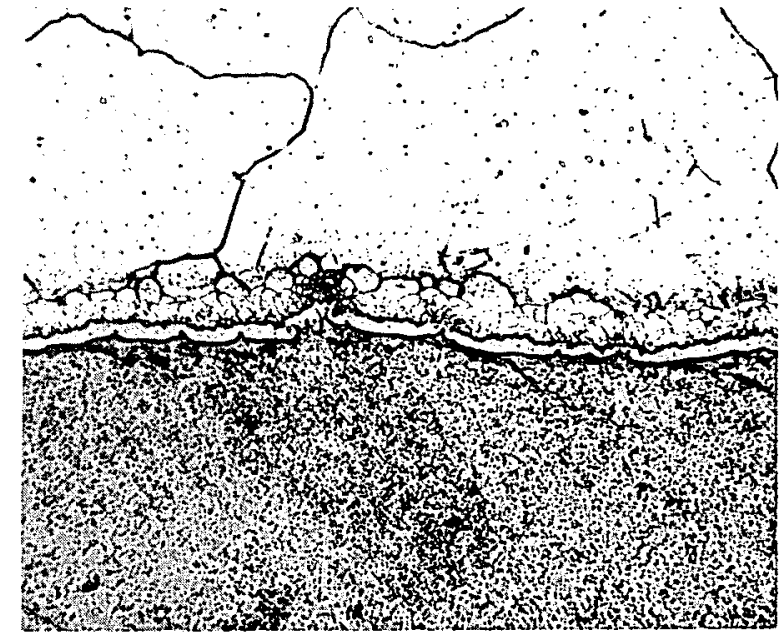

$250 \mathrm{x}$

a) $\operatorname{Rod} 74-4$

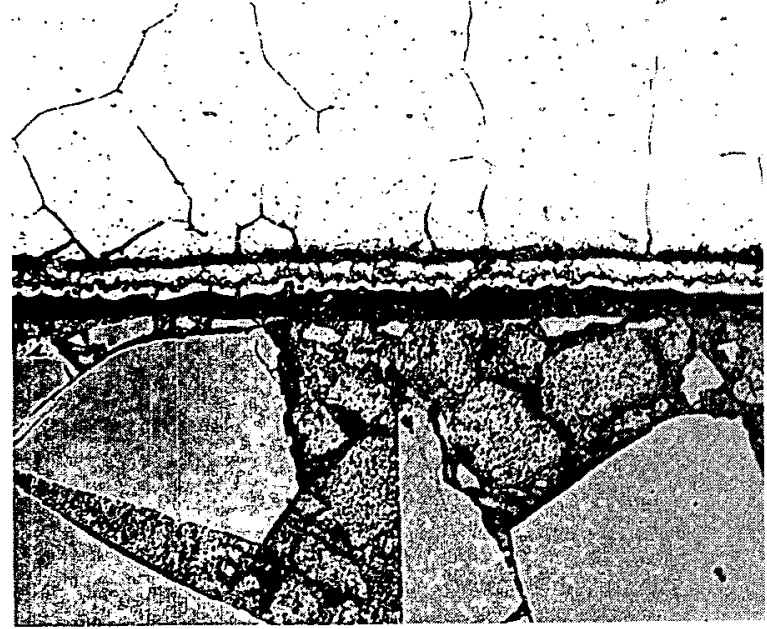

$250 \mathrm{X}$

RM24409

b. $\operatorname{Rod} 76-4$

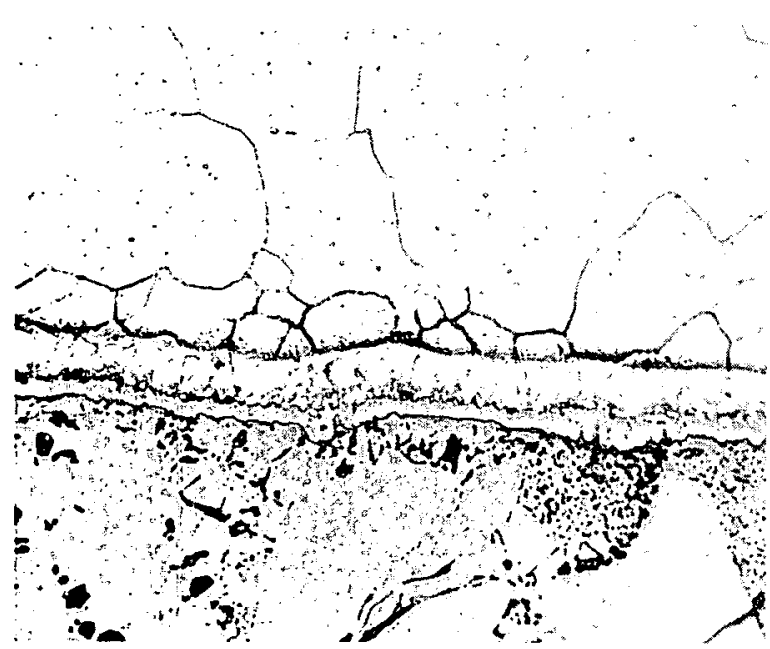

$250 X$
RM24416

c. $\operatorname{Rod} 78-1$

RM24420

$250 \mathrm{X}$
RM24414

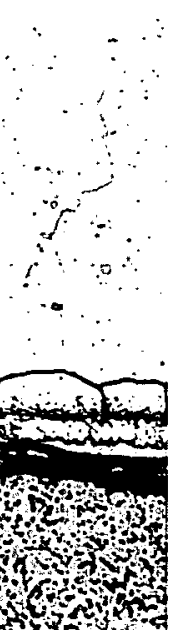

\footnotetext{
d. Rod 80-2
}

FIGURE 5. CORE-CLADDING INTERFACE IN INCONEL X-CLAD UO ${ }_{2}$ FUEL RODS GAS-PRESSURE BONDED 3 HR AT 2100 F AND 10,000 PSI

The continuous light-colored phase separating the $\mathrm{UO}_{2}$ and the Inconel cladding is believed to be $\mathrm{Cr}_{2} \mathrm{O}_{3}$. 


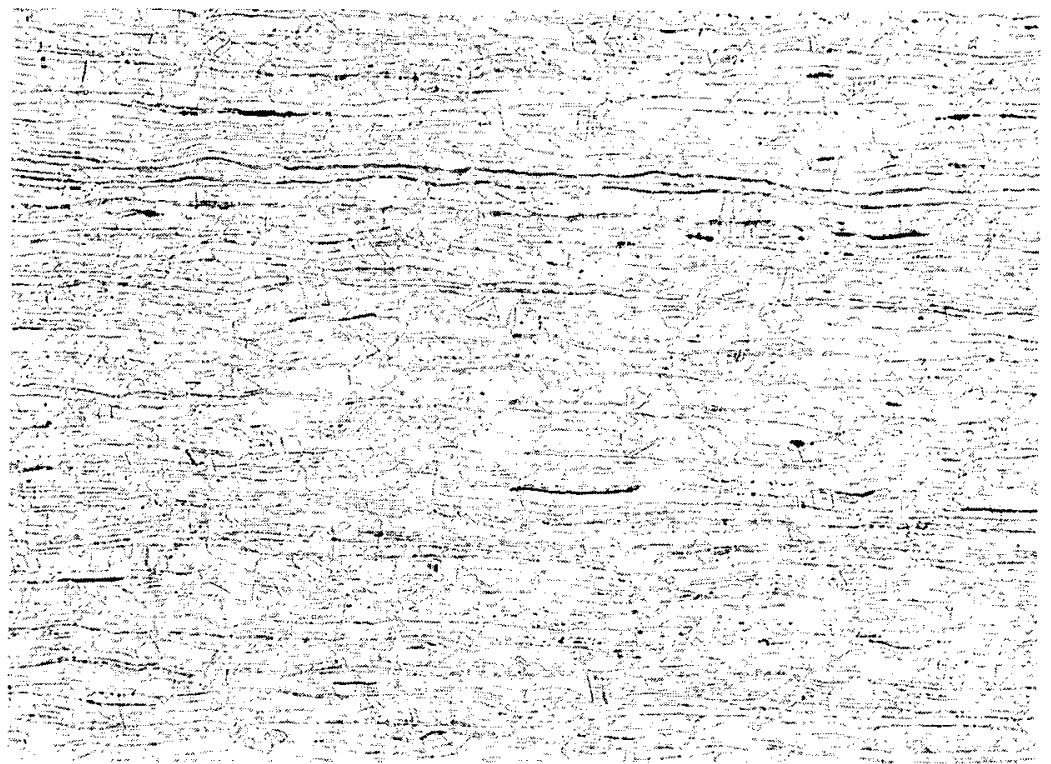

$100 \mathrm{X}$

RM22325

a. Type $304 \mathrm{~L}$ (Grain Size, 6 to 7 )

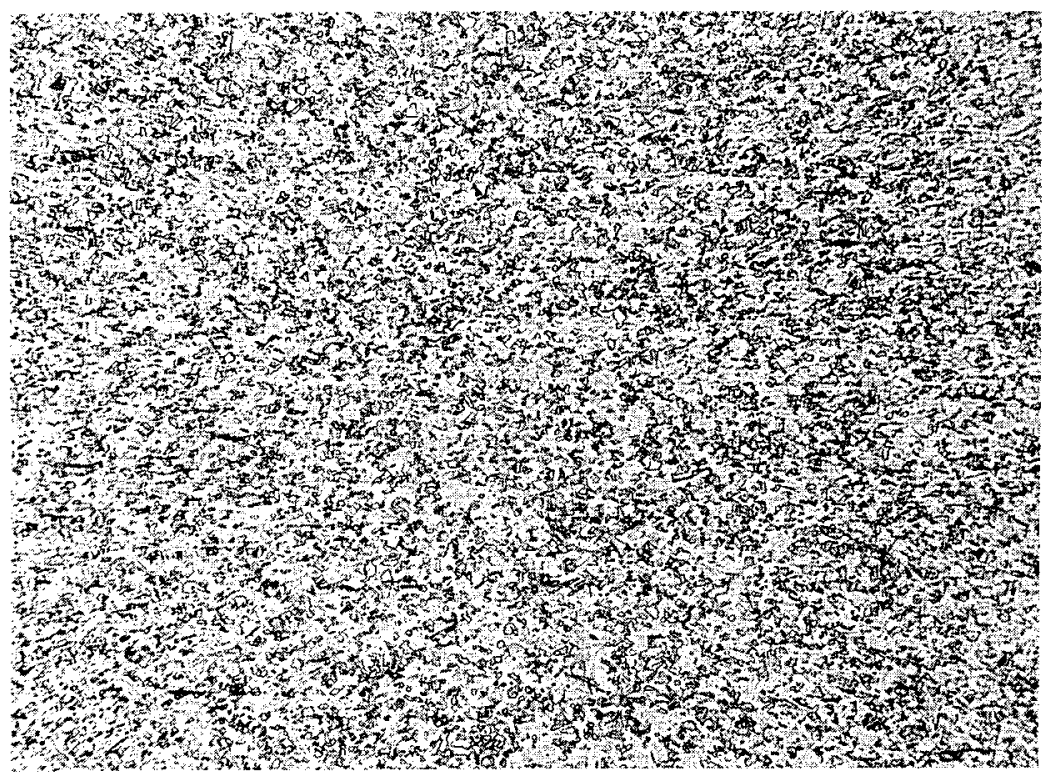
$100 \mathrm{X}$

RM22294

b. Type 347 (Grain Size, 8 )

FIGURE 6. AS-RECEIVED MICROSTRUCTURES OF STAINLESS STEELS USED IN COLD-WORKING STUDY 
TABLE 2. EFFECTS OF PRESSURE BONDING ON GRAIN SIZE OF COLD-ROLLED TYPE 304L STAINLESS STEEL

\begin{tabular}{cccl}
\hline \hline $\begin{array}{c}\text { Reduction by } \\
\begin{array}{c}\text { Cold Rolling, } \\
\text { per cent }\end{array}\end{array}$ & AnTM Grain Size & \\
\cline { 2 - 3 } $\begin{array}{c}\text { Inter } \\
\text { Bonding }(\mathrm{a})\end{array}$ & & $\begin{array}{c}\text { Comments on Grain Structure } \\
\text { After Bonding }\end{array}$ \\
\hline $\begin{array}{c}\text { As received } \\
\text { (annealed) }\end{array}$ & $6-7$ & $2-3$ & Irregular grain growth \\
5 & $6-7$ & $1-3$ & Irregular grain growth \\
10 & $6-7$ & $1-3$ & Irregular grain growth \\
15 & $6-7$ & $2-3$ & Some irregular grain growth \\
20 & $7-8$ & $2-3$ & Irregular grain growth \\
25 & $7-8$ & $2-3$ & Slight irregular grain growth \\
30 & $7-8$ & $2-3$ & Slight irregular grain growth \\
35 & $7-8$ & $3-4$ & Slight irregular grain growth \\
40 & $7-8$ & $3-4$ & Grain size tended toward ASTM 3 \\
45 & $7-8$ & $3-4$ & Average uniform grain size \\
50 & 8 & $3-4$ & Average uniform grain size \\
55 & 8 & $3-4$ & Grain size tended toward ASTM 4 \\
60 & 8 & $2-4$ & Irregular grain growth \\
\hline
\end{tabular}

(a) Pressure bonded for $3 \mathrm{hr}$ at $2100 \mathrm{~F}$ and $10,000 \mathrm{psi}$.

TABLE 3. EFFECTS OF PRESSURE BONDING ON GRAIN SIZE OF COLD-ROLLED TYPE 347 STAINLESS STEEL

\begin{tabular}{cccc}
\hline $\begin{array}{c}\text { Reduction by } \\
\begin{array}{c}\text { Cold Rolling, } \\
\text { per cent }\end{array}\end{array}$ & ASTM Grain Size & $\begin{array}{c}\text { After } \\
\text { Inial }\end{array}$ & $\begin{array}{c}\text { Comments on Grain Structure } \\
\text { After Bonding }\end{array}$ \\
\hline $\begin{array}{c}\text { As received } \\
\text { (annealed) } \\
10\end{array}$ & 5 & 8 & $\begin{array}{c}\text { Very fine average uniform grain } \\
\text { size } \\
\text { Very fine average uniform grain } \\
\text { size } \\
\text { Very fine average uniform grain } \\
\text { size } \\
\text { Very fine average uniform grain } \\
\text { size }\end{array}$ \\
\hline
\end{tabular}

(a) Bonded $3 \mathrm{hr}$ at $2100 \mathrm{~F}$ and $10,000 \mathrm{psi}$. 
A general comparison of microstructures of the different specimens of Types $304 \mathrm{~L}$ and 347 stainless steels after pressure bonding at $2100 \mathrm{~F}$ for $3 \mathrm{hr}$ at $10,000 \mathrm{psi}$ illustrates the effect of cold working on the microstructure of the stainless steels. Figures 7 and 8 show, respectively, the type 304L and Type 347 microstructures, after cold rolling and pressure bonding. It is quite apparent from the microstructures of both types of stainless steels that a large amount of grain growth occurred during gaspressure bonding of the cold-worked specimens. In general, Type 304L stainless steel exhibited a larger grain size than Type 347 steel after cold rolling and pressure bonding. This would be expected since Type 347 stainless in the as-received condition exhibited a finer grain size than the Type $304 \mathrm{~L}$ alloy in the same condition. In either case however, the study showed that the larger grain size exhibited by pressure bonded stainless steels can be reduced by prior cold working in the range of 35 to 50 per cent.

Effect of Prior Cold Work on the Mechanical Properties of Pressure-Bonded Stainless Steels

In order to establish the effects of prior cold work in these materials, hardness and tensile data were obtained on similar specimens. Ultimate strength, yield strength, and elongation were determined from flat tensile specimens gas pressure bonded at $2100 \mathrm{~F}$ for $3 \mathrm{hr}$ at $10,000 \mathrm{psi}$. The hardness values were obtained on a Vickers testing machine employing a $5-\mathrm{kg}$ load. The results are summarized in Tables 4 and 5 . Figures 9 and 10 graphically illustrate the effect of pressure bonding on the hardness of cold-worked Types $304 \mathrm{~L}$ and 347 stainless steels.

It is apparent from both the hardness and tensile data that gas-pressure bonding produced no significant variations in the yield and ultimate strengths of these specimens in tests conducted at room temperature. Elongation values varied from 71 to 79 per cent in the Type $304 \mathrm{~L}$ stainless, with 10 per cent cold worked material exhibiting the highest elongation. The elongation in the Type 347 stainless steel varied from 48 to 52 per cent. Cold rolling the stainless steel raised the hardness values quite considerably in both types of steels; cold rolling and pressure bonding caused a slight reductiois in hardness values for the Type 304L stainless, but no apparent reduction in hardness values occurred with the Type 347 alloy.

The results of the study demonstrated that a marked change in mechanical properties does not occur in stainless steels as a result of gas-pressure bonding. No correlation between mechanical properties and grain size was observed. In any case, the coarse grain size that is present, particularly in Type 304L stainless after pressure bonding can be minimized by prior cold working. As summarized previously in Tables 2 and 3, prior cold working in the range of 35 to 55 per cent promotes a uniform fine regular grain growth in both Type 304L and Type 347 stainless steel during pressure bonding. Irregular grain growth occurs during pressure bonding of annealed Type 304L stainless steel.

The results of this work also show that a finer grain size can be attained through the use of Type 347 stainless steel as compared to Type 304L stainless steel. The finer grained material might be considered more desirable as a fuel cladding material on the basis of possible stress-corrosion effects in service environments. The data presented in this report and corrosion studies in previous reports $(4,5)$ indicate, however, that 
TABLE 4. EFFECT OF GAS-PRESSURE BONDING 3 HR AT $2100 \mathrm{~F}$ AND 10,000 PSI ON THE MECHANICAL PROPERTIES OF TYPE 304L STAINLESS STEEL

\begin{tabular}{|c|c|c|c|c|c|}
\hline \multirow{3}{*}{$\begin{array}{l}\text { Reduction by } \\
\text { Cold Rolling, } \\
\text { per cent }\end{array}$} & \multicolumn{3}{|c|}{ Tensile Properties After Bonding } & \multirow{2}{*}{\multicolumn{2}{|c|}{$\begin{array}{c}\text { Vickers Hardness } \\
(5-\mathrm{Kg} \text { Load })\end{array}$}} \\
\hline & & 0.2 Per Cent & Elongation & & \\
\hline & $\begin{array}{c}\text { Ultimate } \\
\text { Strength, psi }\end{array}$ & $\begin{array}{l}\text { Offset Yield } \\
\text { Strength, psi }\end{array}$ & $\begin{array}{l}\text { in } 2 \text { In. } \\
\text { per cent }\end{array}$ & Initial & $\begin{array}{l}\text { After } \\
\text { Bonding }\end{array}$ \\
\hline $\begin{array}{c}\text { As received } \\
\text { (annealed) }\end{array}$ & 77,800 & 24,100 & 72 & 273 & 186 \\
\hline 5 & -- & -- & -- & 267 & -- \\
\hline 10 & 82,000 & 24,100 & 79 & -- & 183 \\
\hline 15 & -- & - & - & 300 & -- \\
\hline 20 & 81,900 & 23,600 & 78 & -- & 170 \\
\hline 25 & - & -- & -- & 352 & -- \\
\hline 35 & 81,500 & 23,400 & 73 & 374 & 119 \\
\hline 40 & 81,800 & 23,600 & 72 & -- & 129 \\
\hline 45 & 80,900 & 23,900 & 71 & 382 & 119 \\
\hline 55 & -- & -- & -- & 404 & -- \\
\hline
\end{tabular}

TABLE 5. EFFECT OF GAS-PRESSURE BONDING 3 HR AT 2100 F AND 10,000 PSI ON THE MECHANICAL PROPERTIES OF TYPE 347 STAINLESS STEEL

\begin{tabular}{|c|c|c|c|c|c|}
\hline \multirow{2}{*}{$\begin{array}{l}\text { Reduction by } \\
\text { Cold Rolling, } \\
\text { per cent }\end{array}$} & \multicolumn{3}{|c|}{ Tensile Properties After Bonding } & \multicolumn{2}{|c|}{$\begin{array}{c}\text { Vickers Hardness } \\
(5-\mathrm{Kg} \text { Load })\end{array}$} \\
\hline & $\begin{array}{c}\text { Tensile } \\
\text { Strength, psi }\end{array}$ & $\begin{array}{l}\text { Offset Yield } \\
\text { Strength, psi }\end{array}$ & $\begin{array}{l}\text { in } 2 \text { In. } \\
\text { per cent }\end{array}$ & Initial & $\begin{array}{c}\text { After } \\
\text { Bonding }\end{array}$ \\
\hline $\begin{array}{c}\text { As received } \\
\text { (annealed) }\end{array}$ & 89,100 & 30,200 & 52 & 286 & 139 \\
\hline 10 & 86,800 & 28,500 & 50 & 303 & 131 \\
\hline 20 & 89,100 & 29,800 & 52 & 339 & 142 \\
\hline 35 & 93,300 & 33,100 & 48 & 380 & 137 \\
\hline
\end{tabular}




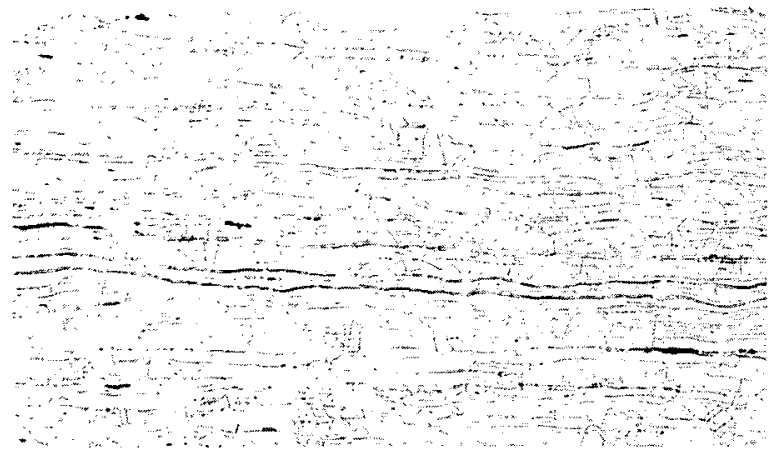

$100 \mathrm{X}$

RM22325

a. As Received (Annealed)

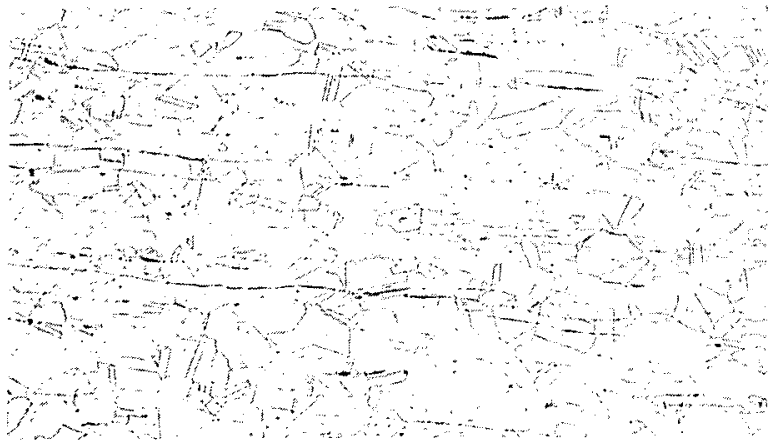

$100 \mathrm{X}$

RM22321

c. Cold Worked 5 Per Cent

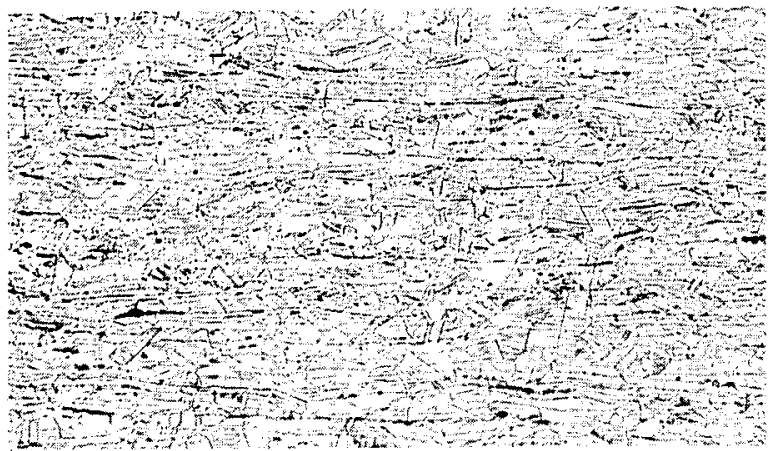
$100 \mathrm{x}$

RM22322

e. Cold Worked 10 Per Cent

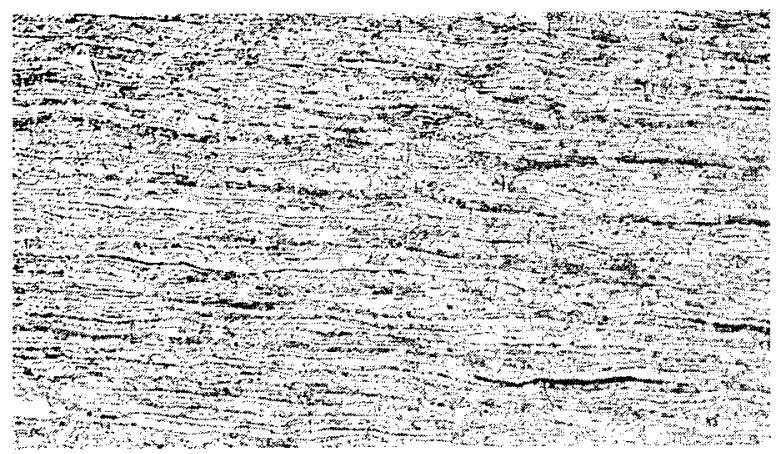

$100 X$

RM22329

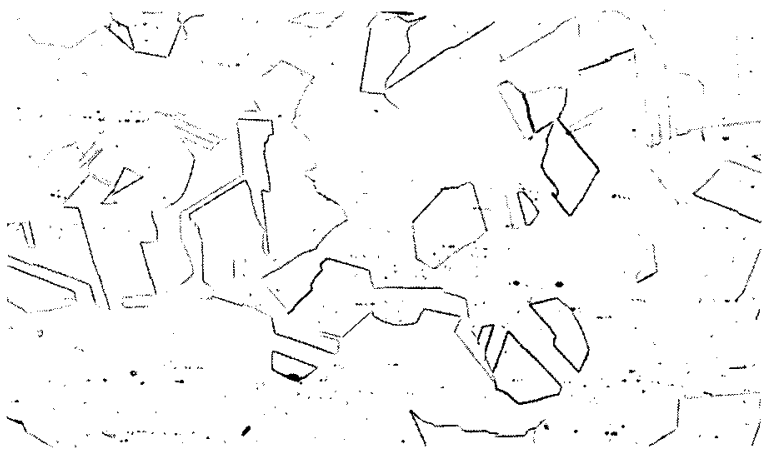

$100 \mathrm{X}$

b. After Pressure Bonding

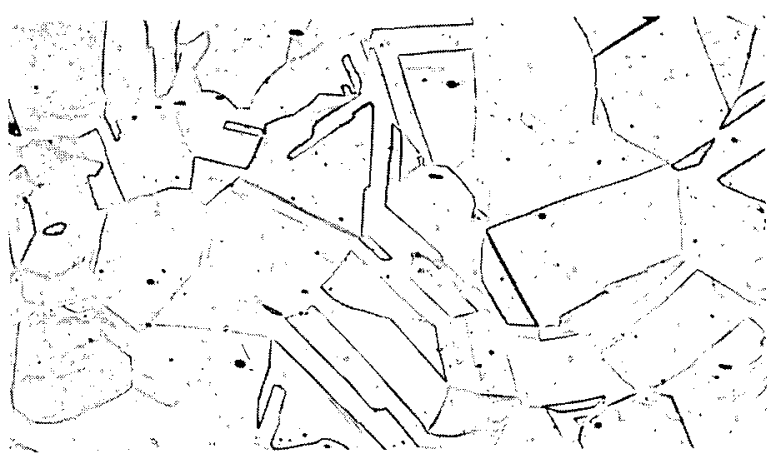

$100 \mathrm{X}$

RM22306

d. After Pressure Bonding

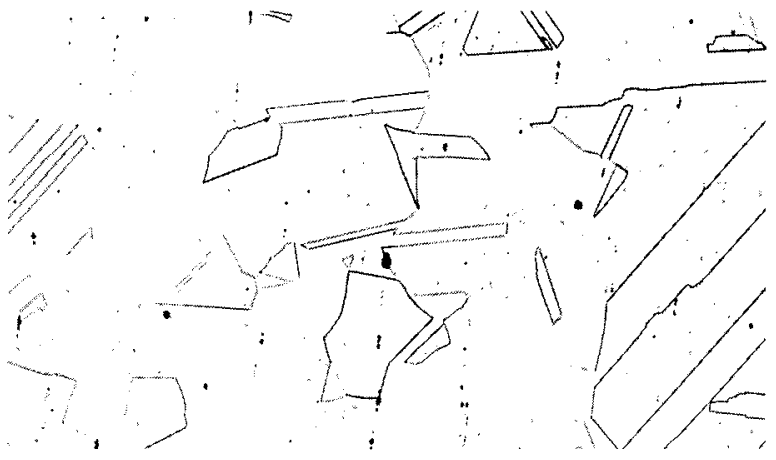

$100 X$

RM22308

f. After Pressure Bonding

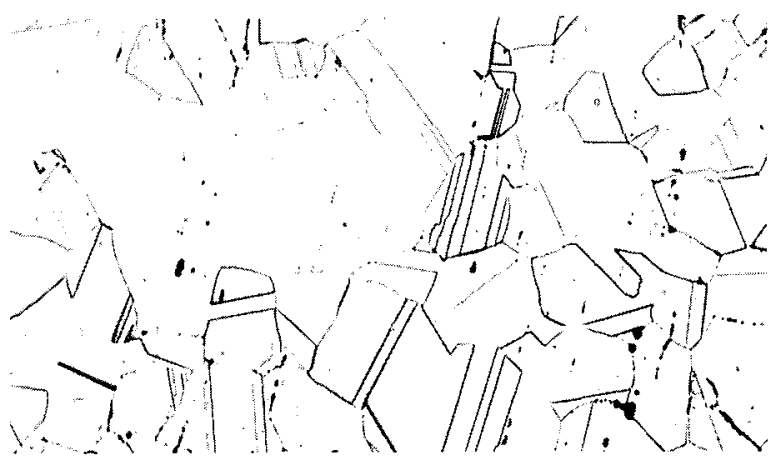

$100 \mathrm{X}$

h. After Pressure Bonding
RM22311

\section{g. Cold Worked 20 Per Cent}

FIGURE 7. EFFECT OF PRIOR COLD WORKING ON THE MICROSTRUCTURE OF TYPE 304L STAINLESS STEEL GAS-PRESSURE BONDED 3 HR AT 2100 F AND 10,000 PSI 


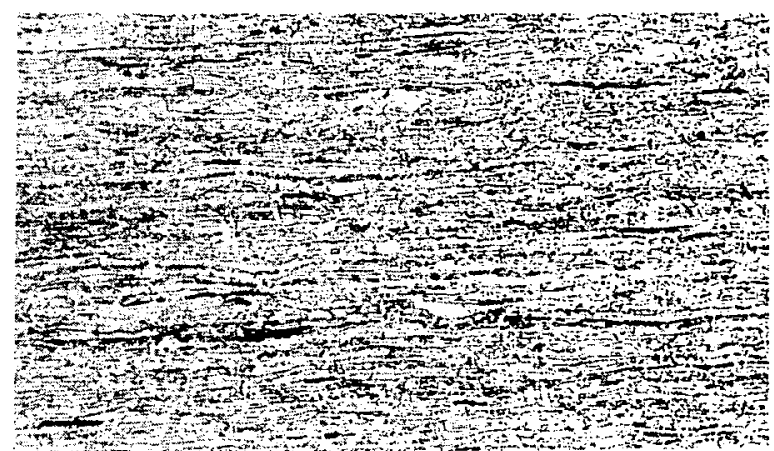

$100 x$

RM22323

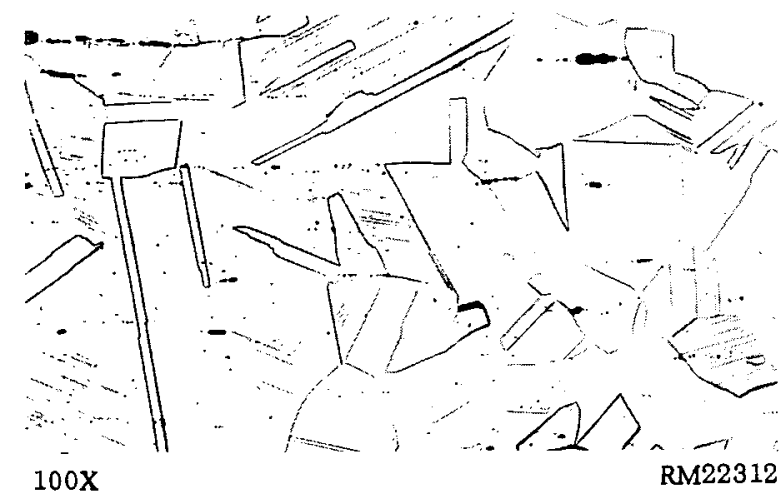

j. After Pressure Bonding

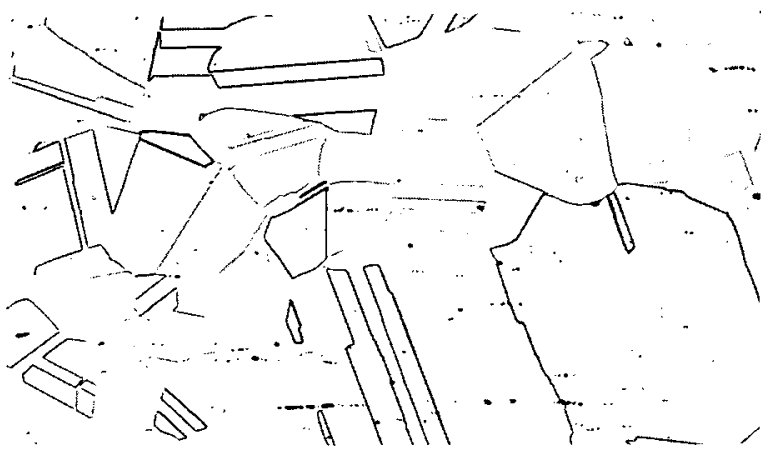

$100 x$

RM22314

1. After Pressure Bonding

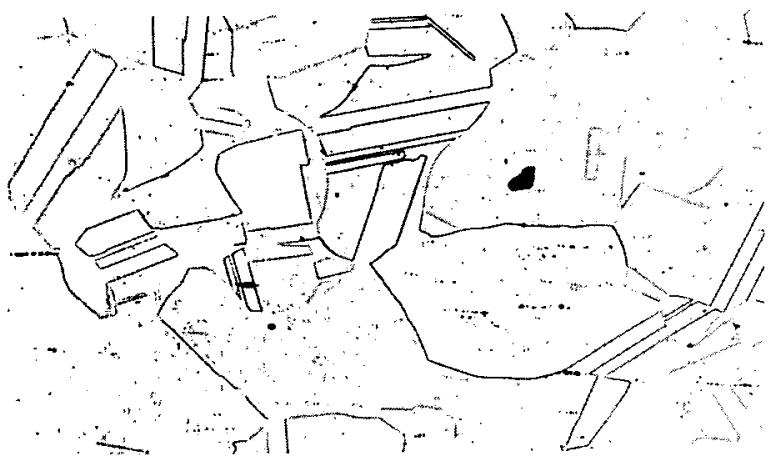

$100 \mathrm{X}$

$\mathrm{RM} 22316$

n. After Pressure Bonding

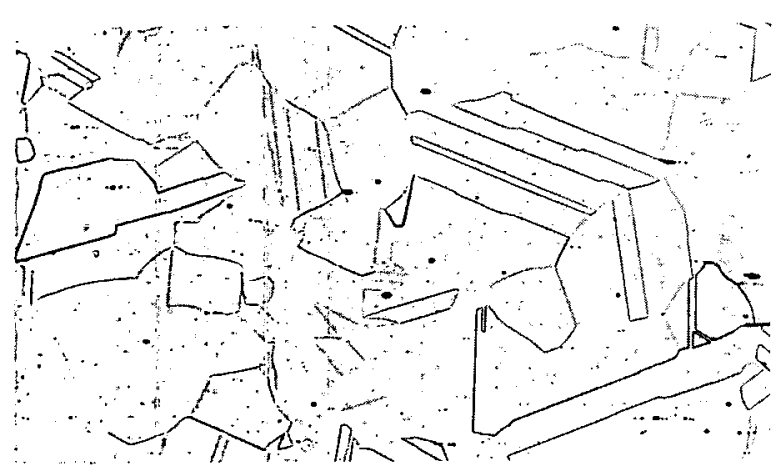

$100 \mathrm{X}$

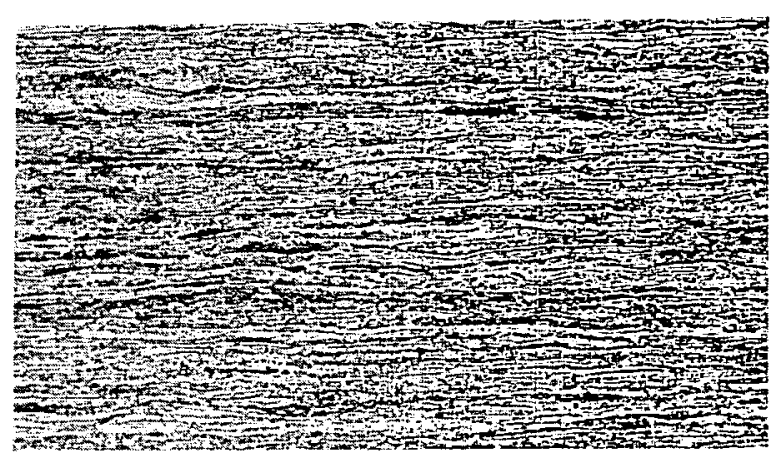

$100 \mathrm{X}$
RM22332

o. Cold Worked 60 Per Cent

p. After Pressure Bonding 


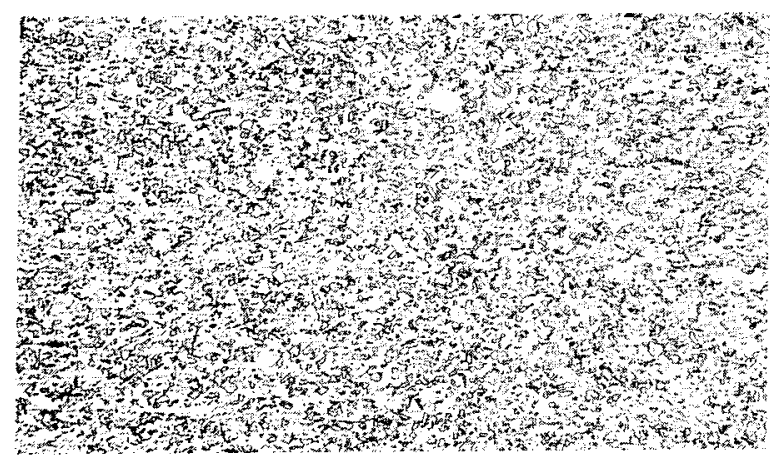

$100 \mathrm{x}$

a. As Received (Annealed)

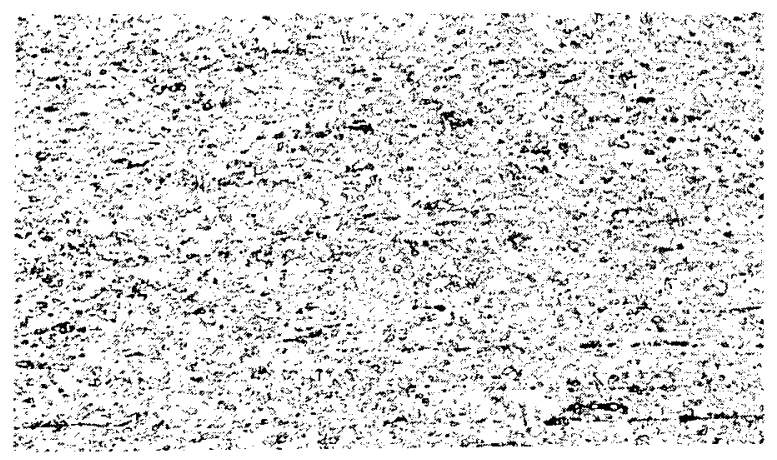

$100 \mathrm{X}$

$\mathrm{RM} 22488$

c. Cold Worked 10 Per Cent

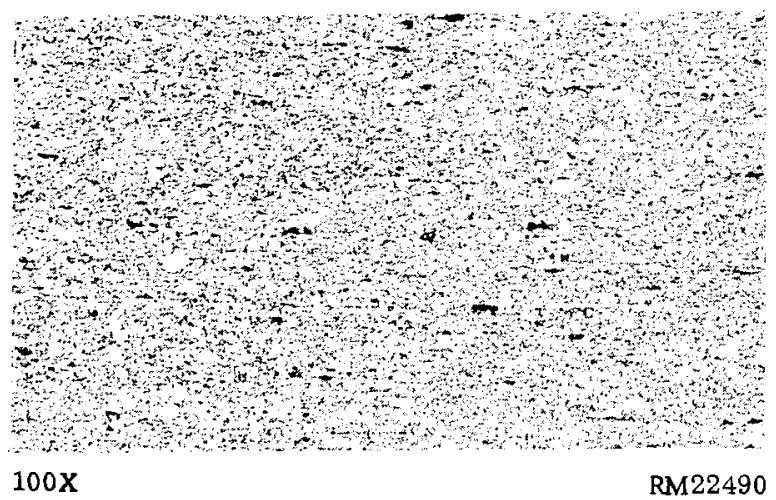

e. Cold Worked 20 Per Cent

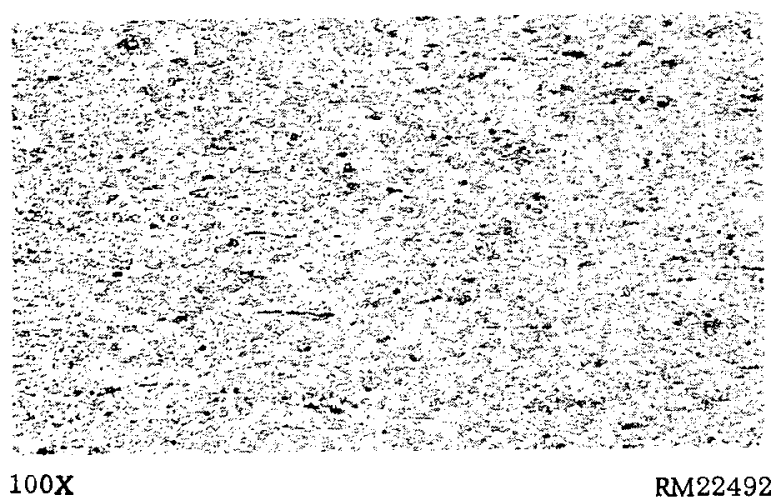

g. Cold Worked 35 Per Cent

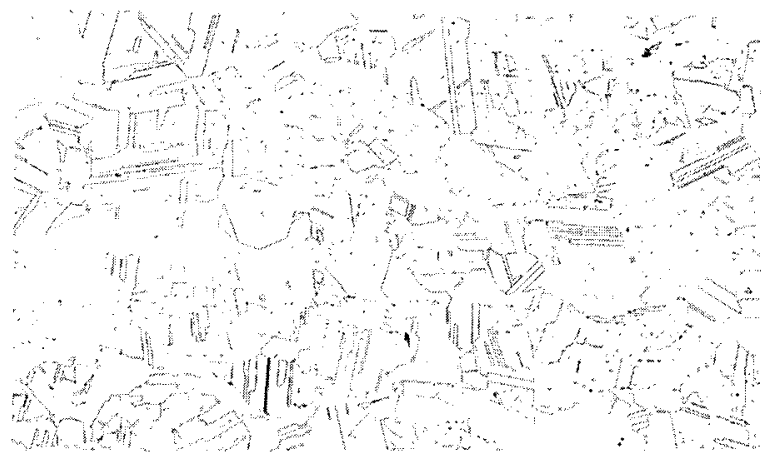

$100 \mathrm{X}$

N94890

b. After Pressure Bonding

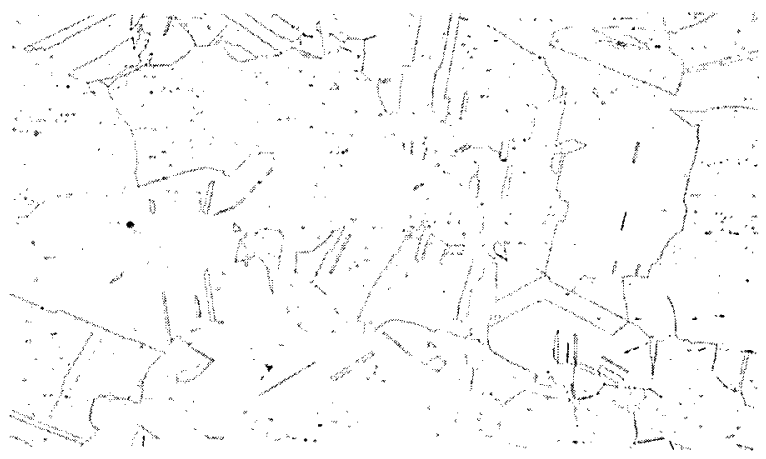

$100 \mathrm{X}$

N94889

d. After Pressure Bonding

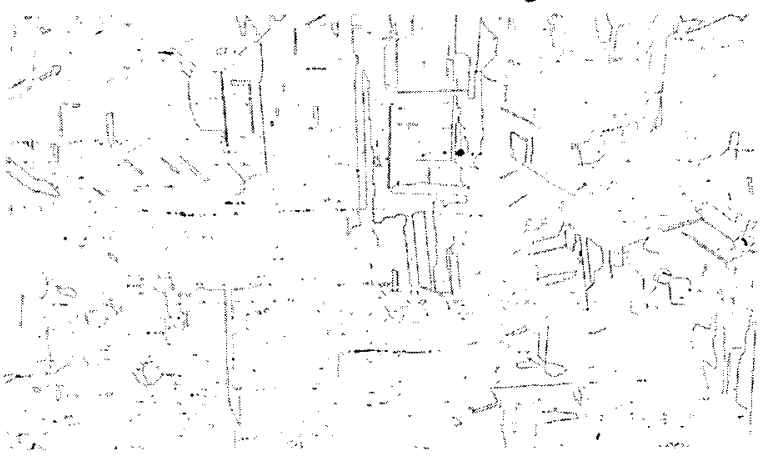

$100 \mathrm{X}$

f. After Pressure Bonding

N94888

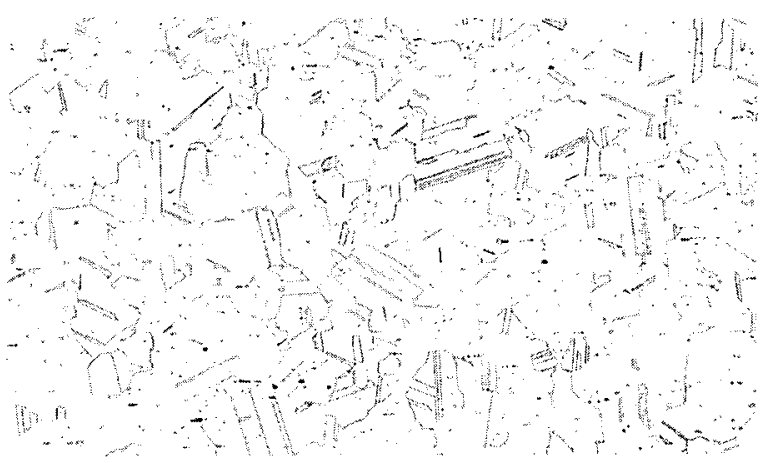

$100 \mathrm{x}$

h. After Pressure Bonding

N94887

FIGURE 8, EFFECT OF PRIOR COLD WORKING ON THE MICROSTRUCTURE OF TYPE 347 STAINLESS STEEL GAS-PRESSURE BONDED 3 HR AT 2100F AND 10,000 PSI 


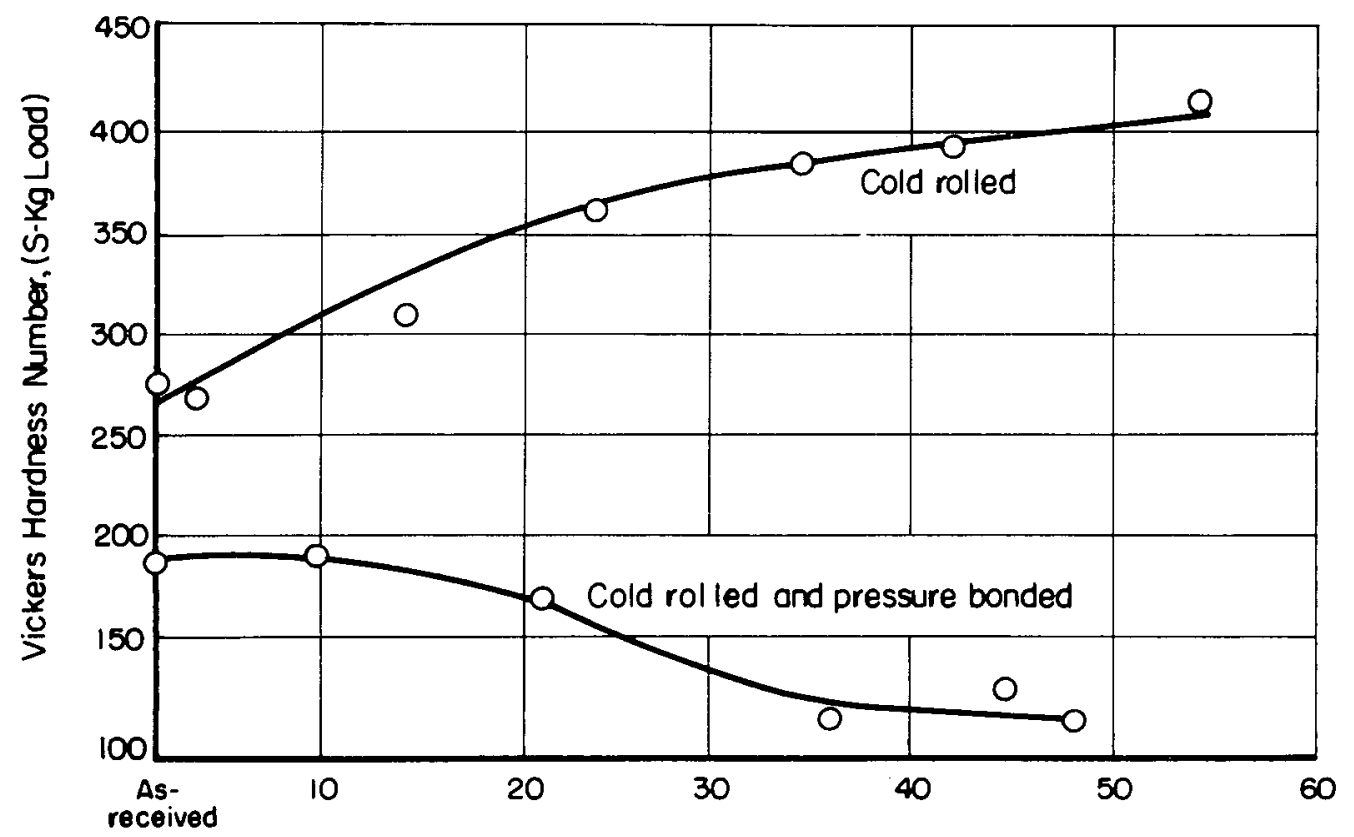

Cold Worked, percent

FIGURE 9. EFFECT OF GAS-PRESSURE BONDING 3 HR AT $2100 \mathrm{~F}$ AND 10,000 PSI ON THE HARDNESS OF COLD-ROLLED TYPE 304L STAINLESS STEEL

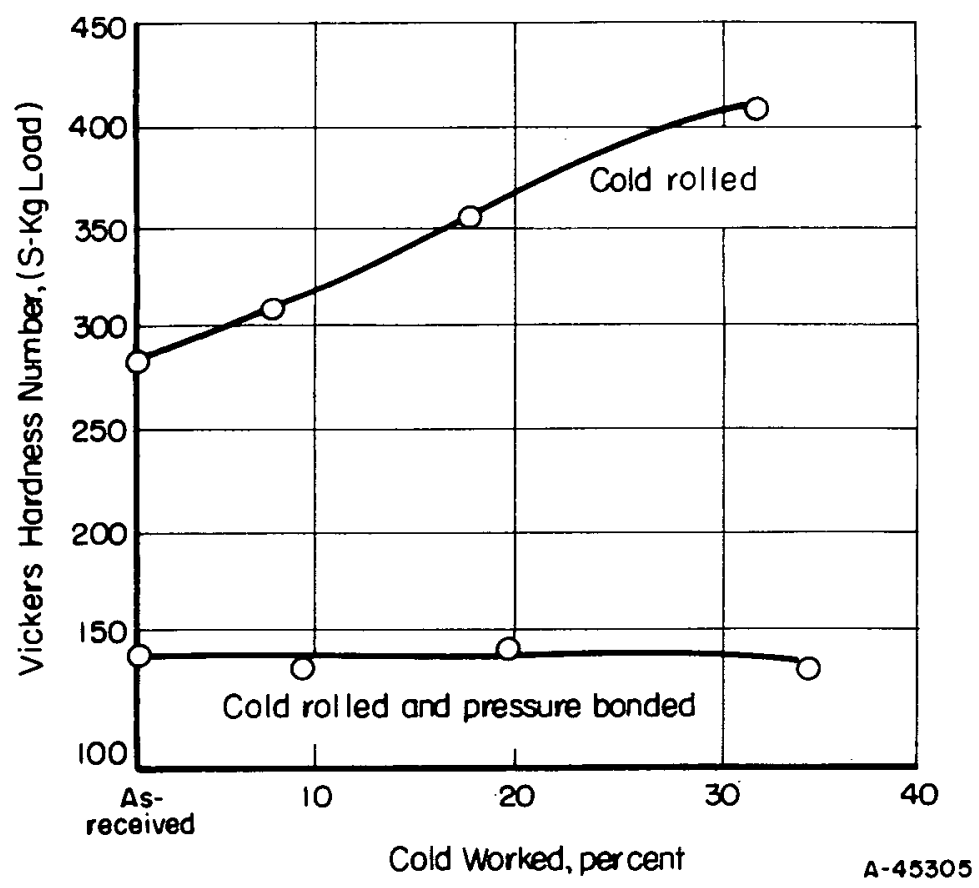

FIGURE 10. EFFECT OF GAS-PRESSURE BONDING 3 HR AT 2100 F AND 10,000 PSI ON THE HARDNESS OF COLD-ROLLED TYPE 347 STAINLESS STEEL 
large grain sizes in low-carbon stainless steels do not significantly affect the mechanica] properties or corrosion resistance in high-temperature water. If a finer initial grain size is considered important, Type 347 stainless steel would be the preferred cladding material for pressure-bonded uranium dioxide fuel elements.

\section{AGGLOMERATION STUDIES OF MICRONIZED URANIUM DIOXIDE}

In view of the difficulties experienced at HAPO with the vibrational compaction characteristics of Micronized uranium oxides, consideration was given to possible methods for agglomerating such powders. By so doing, it appeared possible to increase the uniformity of distribution in packed oxide mixtures and realize a slight increase in packing density. Also, an active oxide such as Micronized oxide which has a high packing density, would permit the use of greater amounts of such oxides in mixtures and potentially, the use of 100 per cent Micronized oxide. This would then result in a significant reduction in the initial oxide cost, particularly if the cost involved in the agglomeration operation is minor. The usefulness of Micronized oxide agglomerated by a cold high-energy forming technique was investigated in conjunction with the series of Inconel $\mathrm{X}$-clad rods described earlier.

Another approach investigated during the course of this program involved the use of hydrostatic pressing and granulation as a means for agglomerating Micronized $\mathrm{UO}_{2}$. In this regard, a limited study of pressures and particle sizes was conducted. Evaluation rods $3 \mathrm{in}$. in length containing hydrostatically agglomerated oxide were then gaspressure bonded to demonstrate possible advantages for use of this material in fuelelement rods.

Characterization of Micronized $\mathrm{UO}_{2}$

The Micronized oxide to be used for the agglomeration studies with the short evaluation rods was received from Hanford. By gravimetric determination the oxygen/ uranium ratio of this oxide was found to be 2.089 ; a value of 2.082 was determined by the polarographic method. A microscopic examination of the Micronized $\mathrm{UO}_{2}$ powder indicated that three phases were present which are described in Table 6. The hydrated phase, $\mathrm{UO}_{2} \cdot \mathrm{nH}_{2} \mathrm{O}$ had not been observed in any $\mathrm{UO}_{2}$ powders previously examined in pressure-bonding studies involving ceramic-grade and Micronized uranium dioxide fuel materials. The size of the extremely small fibers of this hydrated $\mathrm{UO}_{2}$ phase appeared to average approximately 1 to $2 \mu$ in diameter. The presence of this hydrated phase of $\mathrm{UO}_{2}$ could be expected to significantly affect the pressure-bonding characteristics of this Micronized $\mathrm{UO}_{2}$.

A sample of this material was also submitted for examination by means of electron microscopy. The specimens were examined and photographed in an RCA EMU-3E electron microscope. Typical particles are shown in Figure 11 . The range in particle size was from 0.5 to about $4.5 \mu$. Visual optical examination had determined that the average crystal grain size in the sample of $\mathrm{UO}_{2}$ powder was $0.5 \mu$, in agreement with that observed in the electron microscope. The highly irregular shape of the Micronized oxide particles was also evident in this examination. 

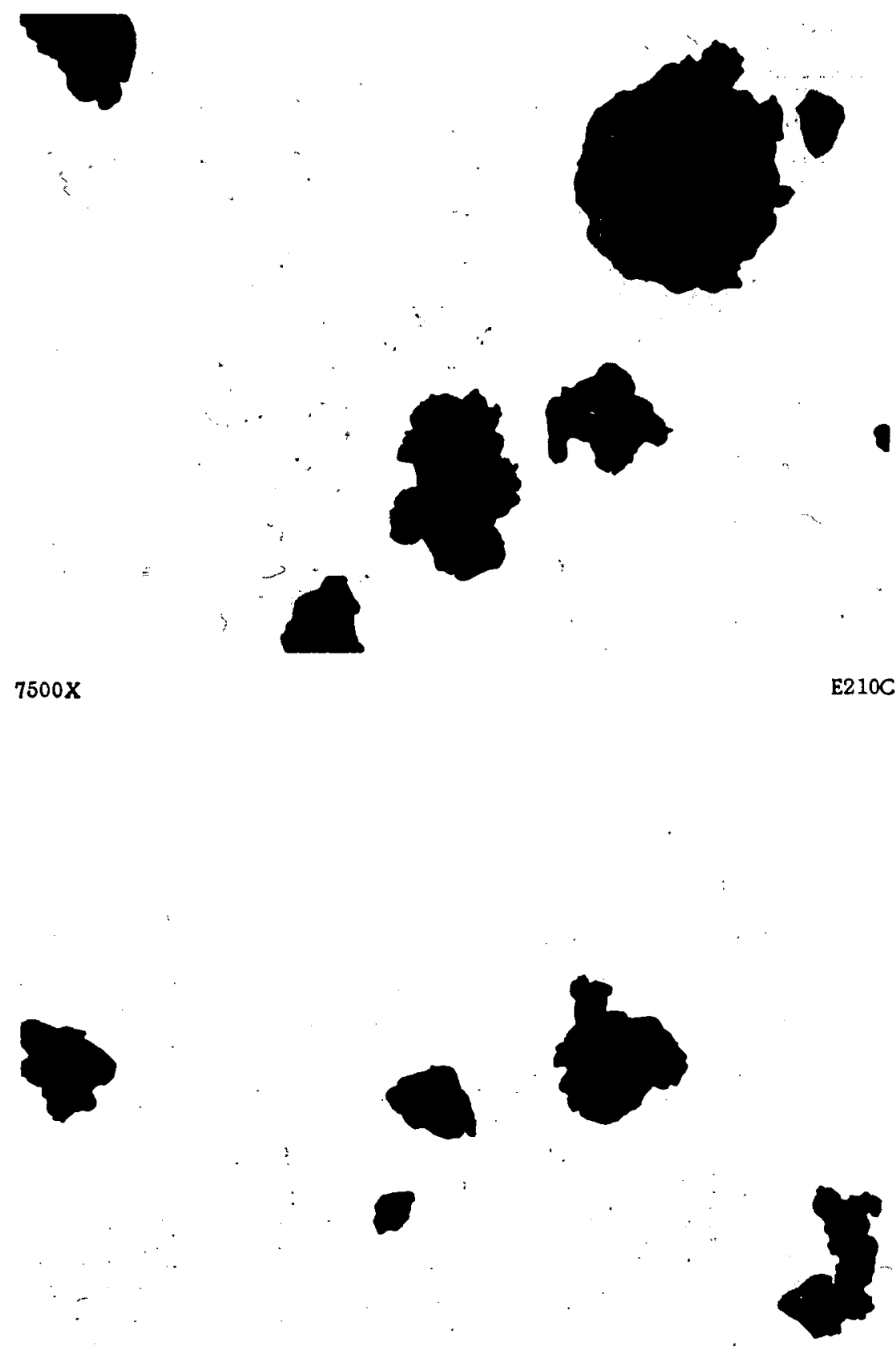

$7500 X$

E210B

FIGURE 11. ELECTRON MICROGRAPHS OF MICRONIZED URA NIUM DIOXIDE POWDER PARTICLES RANGING IN SIZE FROM 0.6 to $4.5 \mu$ 


\section{TABLE 6. RESULTS OF MICROSCOPIC EXAMINATION OF AS-RECEIVED MICRONIZED URANIUM DIOXIDE}

\begin{tabular}{ccc}
\hline $\begin{array}{c}\text { Phase } \\
\text { Composition }\end{array}$ & $\begin{array}{c}\text { Amount of Phase, } \\
\text { volume per cent }\end{array}$ & Comments \\
\hline $\mathrm{UO}_{2}$ & 85.8 & $\mathrm{nH}_{2} \mathrm{O}$ \\
$\mathrm{UO}_{4} \mathrm{O}_{9}$ & 11.5 & $\begin{array}{c}\text { Very fine is otopic grain in modular aggregates } \\
\text { Isotopic, tiny, inclusions, fiberous, and stringy; } \\
\text { amount of combined water not known } \\
\text { Tiny isotopic inclusions; examinations suggest } \\
\text { the composition } \mathrm{U}_{4} \mathrm{O}_{9} \cdot\end{array}$ \\
\hline
\end{tabular}

Hydrostatic Agglomeration of Micronized Uranium Dioxide

To improve the particle packing characteristics of Micronized uranium dioxide, the effect of hydrostatic pressing at various pressures followed by granulating to controlled particle-size fractions was investigated. Cylindrical specimens, approximately 3 in. long by $1 / 2$ in. in diameter, were compacted at four hydrostatic pressures to provide material for this study. The variation of pressed density resulting from these hydrostatic pressures is shown in Figure 12. It is apparent that increasing the hydrostatic pressure above 25,000 psi does not appreciably increase the compacted density of the Micronized UO2.

The compacted Micronized $\mathrm{UO}_{2}$ pressed at four different hydrostatic pressures was then granulated and screened into four particle-size fractions to establish their tappacking characteristics. Each sizing was tap packed separately, and no attempts were made at this time to mix different sizings to achieve increased densities. Table 7 lists the sizings, the hydrostatic pressures, and the tap densities that were obtained with these materials. From these results, it can be noted that only slight increases in tappacked densities were obtained with increased hydrostatic pressure within the range studied. The best tap-packing densities were achieved with the plus 200-mesh sieve sizing in each case. These values compare with a tap density on the order of 20 to 25 per cent of theoretical for the as-received oxide.

Gas-Pressure Bonding of Agglomerated Micronized Uranium Dioxide

Representative size fractions of Micronized oxides along with the as-received material and a mixture of agglomerated oxides were gas-pressure bonded to establish the effects of pressure bonding on the bonding activity of these powders. The powders were loaded by tap packing in 3/8-in.-diameter Type 304L stainless steel tubing measuring 3 to $4 \mathrm{in.} \mathrm{long.} \mathrm{The} \mathrm{ends} \mathrm{of} \mathrm{the} \mathrm{tubing} \mathrm{were} \mathrm{capped} \mathrm{with} \mathrm{stainless} \mathrm{steel} \mathrm{end} \mathrm{plugs.} \mathrm{All}$ assemblies were evacuated and sealed prior to pressure bonding for $3 \mathrm{hr}$ at $2100 \mathrm{~F}$ and $10,000 \mathrm{psi}$. The bonded densities and oxygen/uranium ratios obtained with the se materials are listed in Table 8 . It is apparent that the as-received material, which was included for comparison, yielded a low final density. Similarly, relatively low densities 


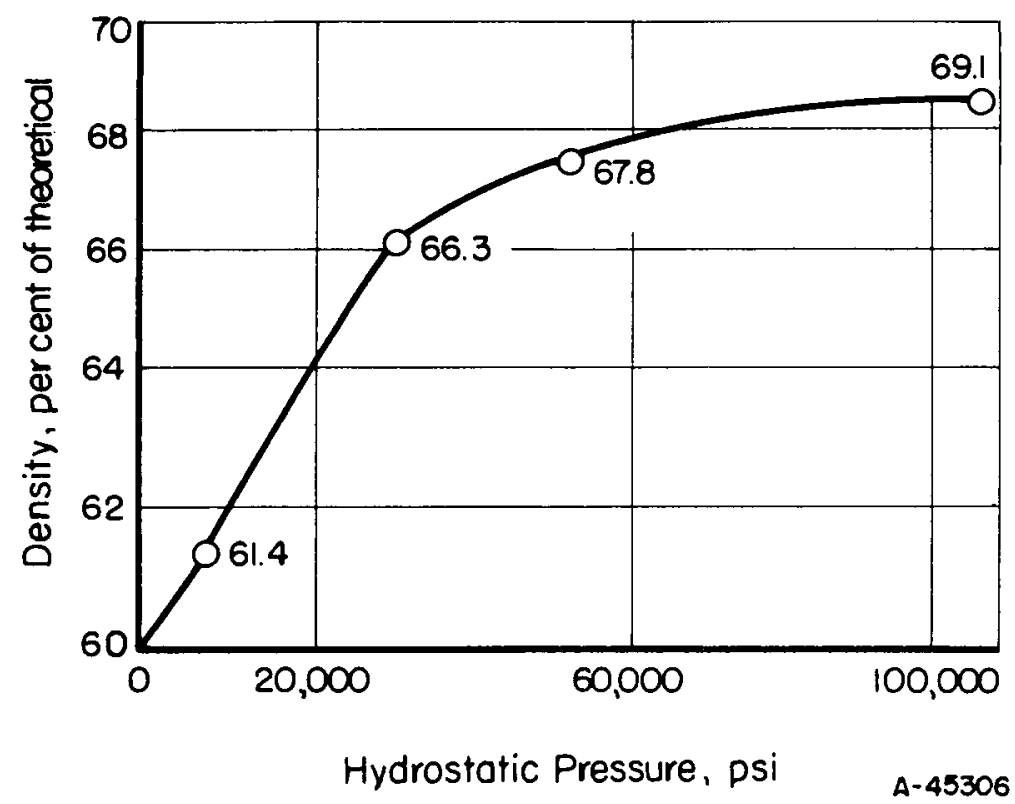

FIGURE 12. VARIATION OF DENSITY OF MICRONIZED URANIUM DIOXIDE WITH HYDROSTATIC PRESSING PRESSURE 
TABLE 7. TAP DENSITIES OF DIFFERENT HYDROSTATICALLY PRESSED AND SIZED MICRONIZED URANIUM DIOXIDE POWDERS

\begin{tabular}{ccc}
\hline $\begin{array}{c}\text { Size of Powder, } \\
\text { U. S. standard mesh }\end{array}$ & $\begin{array}{c}\text { Hgdrostatic } \\
\text { Pressure, psi }\end{array}$ & $\begin{array}{c}\text { Tap Density, } \\
\text { per cent of } \\
\text { theoretical }\end{array}$ \\
\hline$-6+12$ & 10,000 & 32.9 \\
25,000 & 33.6 \\
50,000 & 34.8 \\
100,000 & 37.9 \\
$-30+60$ & 10,000 & 34.7 \\
& 25,000 & 35.4 \\
& 50,000 & 36.5 \\
& 100,000 & 38.3 \\
& 10,000 & 36.5 \\
& 25,000 & 36.7 \\
& 50,000 & 37.8 \\
& 100,000 & 41.3 \\
& 10,000 & 40.6 \\
& 25,000 & 39.7 \\
& 50,000 & 41.2 \\
& 100,000 & 40.8 \\
\hline
\end{tabular}

TABLE 8. EFFECT OF PARTICLE SIZE AND AGGLOMERATION TREATMENT ON THE PROPERTIES OF MICRONIZED UO 2 GAS-PRESSURE BONDED $3 \mathrm{HR} \cdot \mathrm{AT} 2100 \mathrm{~F}$ AND 10,000 PSI

\begin{tabular}{lccc}
\hline & $\begin{array}{c}\text { Properties After Bonding } \\
\text { Sydrostatic } \\
\text { U. S. standard mesh }\end{array}$ & $\begin{array}{c}\text { Agglomeration } \\
\text { Pensity, } \\
\text { Per cent of } \\
\text { theoretical }\end{array}$ & $\begin{array}{c}\text { Oxygen/Uranium } \\
\text { Ratio }\end{array}$ \\
\hline As-received & - & 92.2 & 2.045 \\
Micronized UO 2 & 10,000 & 91.1 & 2.003 \\
$-6+12$ & 50,000 & 89.4 & 2.004 \\
$-30+60$ & 50,000 & 90.1 & 2.007 \\
-200 & 100,000 & 89.7 & 2.006 \\
Mixture of & & & \\
$-6+12$ and & & & \\
-200 & &
\end{tabular}


were achieved with the agglomerated materials. It is interesting to note that previous work with Micronized oxides resulted in densities near theoretical. It is expected that these differences may be related to the presence of the hydrated phase in the Micronized oxide used in the present program. On the other hand, metallographic examination of these bonded oxides indicated densities higher than those measured, as demonstrated in Figure 13. In these structures the extent of porosity normally associated with densities on the order of 90 per cent of theoretical is not evident.

Characterization of Pressure-Bonded Agglomerated Micronized Uranium Dioxide

In order to determine if the hydrated uranium dioxide phase, $\mathrm{UO}_{2} \cdot \mathrm{nH}_{2} \mathrm{O}$ was present after gas-pressure bonding, two different pressure-bonded samples were microscopically examined. The results of this examination are listed in Table 9. Three phases were present in the pressure-bonded samples in similar amounts. In particular, the hydrated phase, $\mathrm{UO}_{2}$ in $\mathrm{H}_{2} \mathrm{O}$, was still present. These results can be compared to those in Table 6, which characterizes the as-received Micronized uranium dioxide, to reveal that there were only slight changes in the amounts of the three phases noted. The continued presence of this hydrated phase could be the cause for the low measured densities of the agglomerated $\mathrm{UO}_{2}$ reported in Table 8 . As noted previously, the metallographic examination of the bonded oxides indicated densities higher than those reported in Table 8. However, it is likely that the theoretical density of the oxide in this series of specimens is somewhat less than that for single-phase $\mathrm{UO}_{2}$. Consequently, the values measured with these materials would appear low compared with previous values.

TABLE 9. RESULTS OF MICROSCOPIC EXAMINATION OF MICRONIZED URANIUM DIOXIDE GAS-PRESSURE BONDED AT $2100 \mathrm{~F}$ FOR 3 HR AT 10,000 PSI

\begin{tabular}{|c|c|c|c|}
\hline \multirow[b]{2}{*}{$\begin{array}{c}\text { Size of Powder, } \\
\text { U. S. standard mesh } \\
\end{array}$} & \multirow[b]{2}{*}{$\begin{array}{c}\text { Hydrostatic } \\
\text { Agglomeration } \\
\text { Pressure, psi }\end{array}$} & \multicolumn{2}{|c|}{$\begin{array}{c}\text { Phase Composition After } \\
\text { Pressure Bonding }\end{array}$} \\
\hline & & Phase & $\begin{array}{l}\text { Amount, } \\
\text { volume } \\
\text { per cent } \\
\end{array}$ \\
\hline-200 & 50,000 & $\begin{array}{c}\mathrm{UO}_{2} \\
\mathrm{UO}_{2} \text { in } \mathrm{H}_{2} \mathrm{O} \\
\mathrm{U}_{4} \mathrm{O}_{9}\end{array}$ & $\begin{array}{r}81.2 \\
13.3 \\
5.5\end{array}$ \\
\hline $\begin{array}{l}\text { Mixture of } \\
-6+12 \\
-200\end{array}$ & 100,000 & $\begin{array}{c}\mathrm{UO}_{2} \\
\mathrm{UO}_{2} \text { in } \mathrm{H}_{2} \mathrm{O} \\
\mathrm{U}_{4} \mathrm{O}_{9}\end{array}$ & $\begin{array}{r}85.0 \\
10.0 \\
5.0\end{array}$ \\
\hline
\end{tabular}




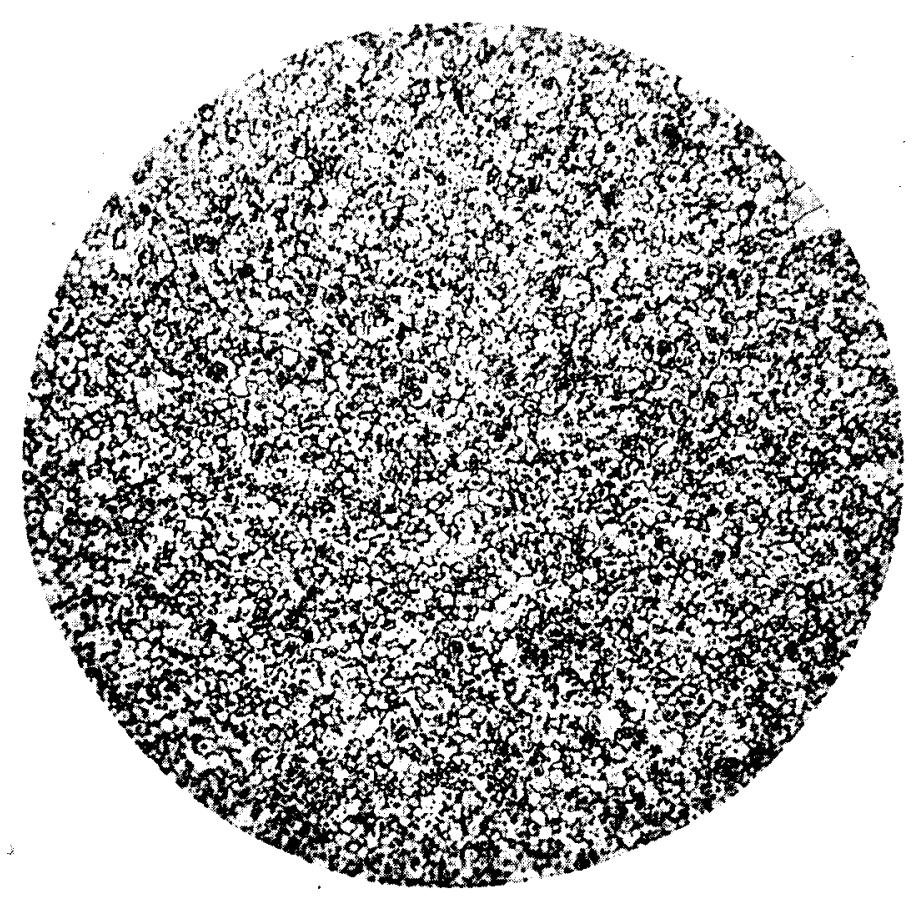

$500 x$

RM23784

a. Prepared From As-Received Powder and Bonded to a Measure Average Density of 92.2 Per Cent of Theoretical

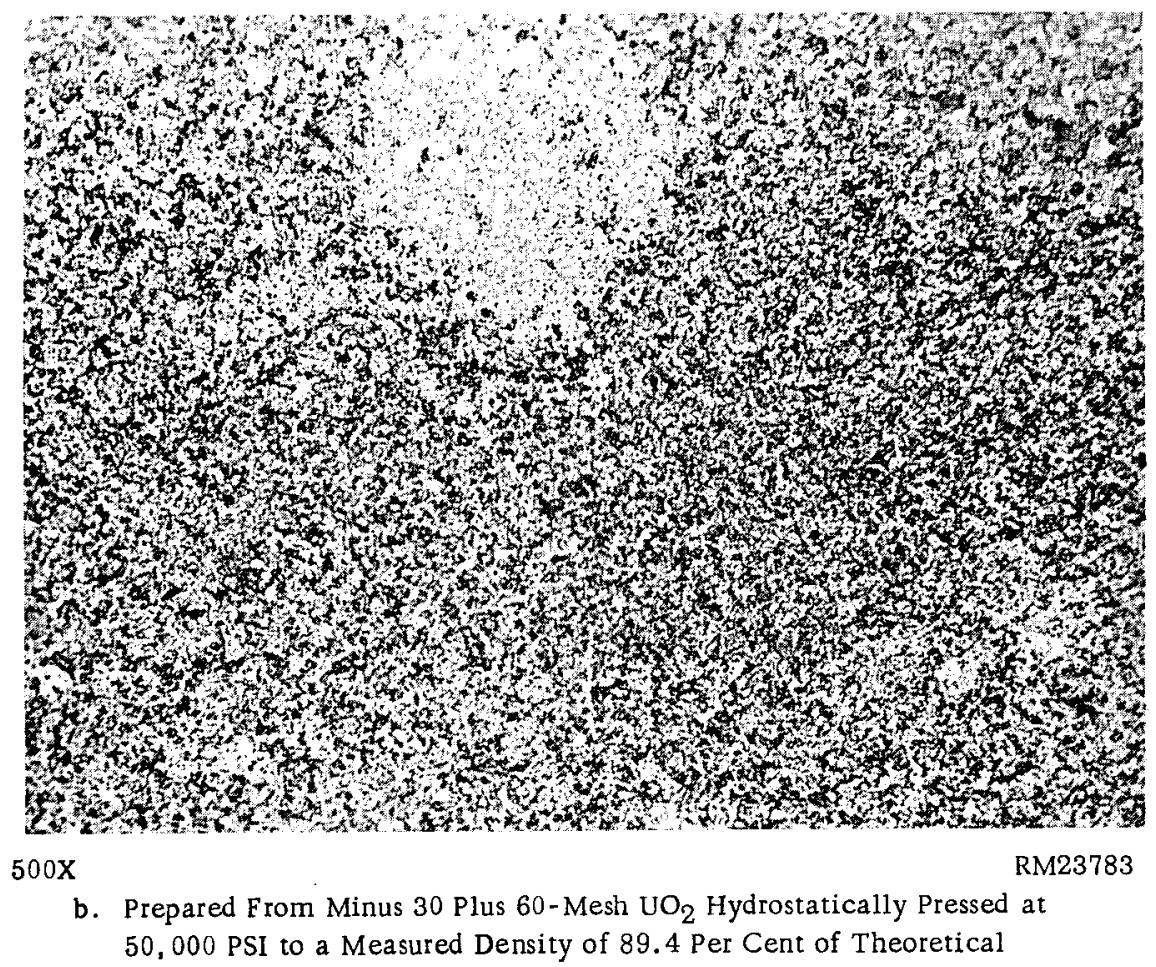

FIGURE 13. TYPICAL MICROSTRUCTURES OF MICRONIZED UO ${ }_{2}$ AFTER GAS-PRESSURE BONDING $3 \mathrm{HR}$ AT $2100 \mathrm{~F}$ AND 10,000 PSI

Densification appears to be more complete than indicated by the measurements. 
Discussion of Results of Agglomeration Study

The usefulness of hydrostatic pressing for agglomeration as a method for increasing the packing density of Micronized uranium has been demonstrated in the current program. The tap density can be increased from 20 to 25 per cent of theoretical for the as-recieved Micronized ceramic dioxide to as high as 41 per cent of theoretical density by this method. In general it was noted that hydrostatic pressures in excess of 50, 000 psi offer very little improvement in the density of the pressed material and the tap density of powder of the particle-size fractions investigated. Particle size after agglomeration also contributed significantly to the tap density of the material; however a more detailed study would be required to optimize this factor.

From a comparison of these results with previous data, it is apparent that variations in the starting Micronized oxide can result in significant variations in the pressurebonded oxide. This effect, which was noted in the bonded agglomerated materials, most likely contributed to the lower densities exhibited by the vibrationally compacted and pressure-bonded Inconel $\mathrm{X}$ fuel rods. In these cases, the presence of a hydrated phase of uranium dioxide, $\left(\mathrm{UO}_{2} \cdot \mathrm{nH}_{2} \mathrm{O}\right)$ appeared to lower the final density of the gas-pressurebonded oxide materials. This effect demonstrates the need for close control of the characteristics of the starting oxide material.

\section{CONCLUSIONS}

From this study of the influence of oxide composition and predensification method on pressure-bonded $\mathrm{UO}_{2}$ fuel rods, of the effect of cold working on the properties of pressure-bonded stainless steels, and of the use of hydrostatic agglomeration techniques for Micronized oxide, the following conclusions can be obtained:

(1) Use of cold high-energy-formed uranium dioxide in the fabrication of fuel rods by the combined processes of vibrational compaction and gaspressure bonding was successful. The ceramic activity of the Micronized oxide in this form was retained.

(2) Inconel $\mathrm{X}$ cladding appeared to behave in a more brittle manner during pressure bonding than the stainless steels studied previously.

(3) The high oxygen-to-uranium ratios and low densities that characterized the pressure-bonded Inconel $X$ fuel rods cannot be considered typical results of this fabrication technique since rod-type fuel elements made in previous gas-pressure-bonding studies did not exhibit these effects. The behavior could possibly be attributed to the presence of a hydrated uranium dioxide phase in the ceramic core.

(4) Agglomeration of Micronized uranium dioxide by hydrostatic pressing is a successful method for increasing the initial density prior to fuel-element assembly and at the same time retaining the necessary ceramic activity for pressure bonding. The presence of a hydrated uranium dioxide phase in the starting Micronized oxide significantly lowered the final bonded density and also resulted in a high oxygen-to-uranium ratio in the final bonded rods. 
(5) Cold working of Type $304 \mathrm{~L}$ and Type 347 stainless steels in the range of 35 to 50 per cent prior to pressure bonding will give a structure with a fine grain size after pressure bonding.

(6) Gas-pressure bonding does not affect significantly the mechanical properties of Type $304 \mathrm{~L}$ and Type 347 stainless steels, although a large range of grain sizes was represented in these tests.

(7) As a result of a finer initial grain size, Type 347 stainless steel would be more preferred as a cladding material than Type $304 \mathrm{~L}$ stainless steel.

\section{REFERENCES}

(1) Hauth, J. J., "Vibrational Compacted Ceramic Fuels", Nucleonics, 20 (9), 50-54 (September, 1962).

(2) Paprocki, S. J., ed., "Progress on the Use of Gas-Pressure Bonding for Fabricating Low-Cost Ceramic, Cermet, and Dispersion Fuels, Phase I Report on AEC Fuel-Cycle Program", BMI- 1372 (August 25, 1959).

(3) Paprocki, S. J., ed., "Progress on the Use of Gas-Pressure Bonding for Fabricating Low-Cost Ceramic, Cermet, and Dispersion Fuels, Phase II Report on AEC Fuel-Cycle Program", BMI- 1475 (November 7, 1960).

(4) Porembka, S. W., Boyer, C. B., and Hauth, J. J., "Fabrication of UO2 Fuel Rods by Vibration Packing and Pressure Bonding", BMI- 1637 (June 28, 1963).

(5) Paprocki, S. J., ed., "Progress on the Use of Gas-Pressure Bonding for Fabricating Low-Cost Ceramic, Cermet, and Dispersion Fuels, Final Report on AEC FuelCycle Program", BMI- 1555 (November 24, 1961).

(6) Paprocki, S. J., Porembka, S. W., Hodge, E. S., and Boyer, C. B., "GasPressure Bonding of Stainless Steel-Clad UO 2 Flat-Plate Elements", BMI-1597 (October 5, 1962).

ESH:SWP:CBB: RJD/jh 